\title{
Recent Health and Safety Incident Trends Related to the Storage of Woody Biomass: A Need for Improved Monitoring Strategies
}

\author{
Sally Krigstin ${ }^{1, *(1)}$, Suzanne Wetzel ${ }^{2}$, Nivatha Jayabala ${ }^{1}$, Christopher Helmeste ${ }^{1}$, \\ Sebnem Madrali ${ }^{3}$, Joy Agnew ${ }^{4}$ and Sylvain Volpe ${ }^{5}$ \\ 1 Faculty of Forestry, University of Toronto, 33 Willcocks St., Toronto, ON M5S 3B3, Canada; \\ nivatha.jayabala@mail.utoronto.ca (N.J.); c.helmeste@mail.utoronto.ca (C.H.) \\ 2 Canadian Wood Fibre Centre (Natural Resources Canada), 580 Booth St., Ottawa, ON K1A 0E4, Canada; \\ suzanne.wetzel@canada.ca \\ 3 CanmetENERGY (Natural Resources Canada), 1 Haanel Dr., Ottawa, ON K1A 1M1, Canada; \\ sebnem.madrali@canada.ca \\ 4 Prairie Agricultural Machinery Institute (PAMI), 2215 8th Avenue, Humboldt, SK S0K 2A0, Canada; \\ jagnew@pami.ca \\ 5 FPInnovations, 570 Saint-Jean Blvd, Pointe-Claire, QC H9R 3J9, Canada; Sylvain.Volpe@fpinnovations.ca \\ * Correspondence: sally.krigstin@utoronto.ca; Tel.: +1-416-946-8507
}

Received: 31 July 2018; Accepted: 29 August 2018; Published: 1 September 2018

\begin{abstract}
Self-heating fires, dust explosions and off-gassing during biomass storage are serious hazards which can have devastating consequences, resulting in worker fatalities and health impacts, as well as bioenergy plant destruction and complete loss of production. A compilation of incident reports involving biomass storage from 2000-2018 has revealed that these potential hazards continue to be a major concern in the bioenergy sector. Higher occurrence rates were found for incidents categorized as self-heating fires and fires of uncertain causes in recent years through our study of online reports. This paper highlights a critical need for improved safety protocols for bioenergy plant workers, detailed incident documentation and enhanced biomass monitoring strategies to drastically reduce the occurrence of threats associated with the storage of woody biomass. In order to manage the high risks associated with self-heating, a system for real-time monitoring of internal pile temperature was investigated. A monitoring system supplied by Braingrid Corporation was verified using embedded Tinytag thermologgers indicating that this methodology shows potential for preventing spontaneous combustion events by providing real time temperature data for superior pile management.
\end{abstract}

Keywords: biomass storage; woody biomass; incident trends; accident reports; safety; bioenergy; self-heating; fires; pile monitoring

\section{Introduction}

Expansion of the bioenergy sector has been driving the necessity for increased large-scale woody biomass storage capacity to ensure a stable supply of fuel can be provided for conversion processes. As storage requirements rise, the health and safety risks associated with storage of biomass, such as worker injuries due to respiratory illnesses, asphyxiation and fatalities, continue to pose serious risks due to spontaneous fires, dust explosions, off-gassing and biological hazards. Janze (2011) reports the factors that influence the occurrence of accidents in biomass systems include that biomass is susceptible to freezing, is dusty, extremely flammable, contains a variety of contaminants, and self-combusts [1]. Sovacool et al. (2016) examined the frequency of energy accidents (defined as "an unintentional 
incident or event at an energy facility that led to either one or more deaths or at least $\$ 50,000$ in property damage overtime" ${ }^{\prime \prime}$ ) and found that accidents occurred at moderate levels for the bioenergy sector compared to other renewable energy systems such as nuclear, hydro, and wind (higher risk systems) as well as solar and geothermal (lower risk) [2]. The data in a study by Moreno and Cozzani (2015) showed that the number of major accidents in the bioenergy sector has been increasing in recent years [3], which reinforces the importance of risk awareness and safe practices in bioenergy production. This study focuses specifically on reported incidents encountered with the storage of woody biomass (hereby defined as wood chips, bark, wood pellets and saw dust).

Self-heating is a process which can become potentially hazardous in large biomass piles when the internal temperature of the pile increases over time, escalating to conditions where combustion can occur [4]. This heating arises due to energy released from living cell respiration (both metabolic microbiological growth and parenchyma cell respiration), thermo-chemical oxidation of biomass as well as other heat-producing physical processes (e.g., moisture absorption) [5-7]. Several different types of microorganisms will colonise wood chips as conditions become favourable for their growth (e.g., temperatures of $15-60{ }^{\circ} \mathrm{C}$, moisture levels above fibre saturation point (fsp), and appropriate $\mathrm{O}_{2}$ and $\mathrm{CO}_{2}$ concentrations) [5]. It is this colonisation that contributes to the initial rapid increase in the temperature of a pile which then accelerates chemical oxidation processes and/or makes the environment more suitable for other, more destructive microorganisms [8]. Fungal degradation of stored woody biomass will also readily occur when favourable conditions such as moisture content of $30 \%-50 \%$, suitable temperature range, and $\mathrm{O}_{2}$ levels are present. Finally, the direct chemical oxidation of wood constituents (which can occur at elevated or ambient temperatures) is also responsible for the temperature rise in wood chip piles once metabolic energy generation has occurred $[9,10]$. When temperatures exceed $80{ }^{\circ} \mathrm{C}$, exothermic oxidation reactions contribute to self-heating and auto-ignition becomes possible [10].

Another possible hazard when storing woody biomass is the potential occurrence of dust explosions. Dust explosions can cause major infrastructure damage, be difficult to anticipate, and occur rapidly in contrast to the gradual escalation of heat in the case of self-heating fires. A dust explosion involves the rapid combustion of dust particles that releases energy and generates gaseous reaction products such as $\mathrm{CO}_{2}$ and water vapour, leading to a build-up of pressure or uncontrolled expansion effects [11,12]. The source of the dust in biomass storage facilities comes from the handling of biomass, which can liberate significant amounts of dust into the air and lead to the gradual accumulation of dust on the ceiling and other parts of the infrastructure. When a dust cloud ignites in an enclosed volume, it results in a very rapid rise in pressure within the contained area, such as a building or storage silo. This phenomenon is catastrophic when the building is not designed to withstand the sudden high pressure or explosion. Anyone close to an exploding plant, or inside a room where an explosion occurs is likely to be killed or seriously injured due to the sudden building collapse or infrastructure failure. The lower explosive limit for many organic materials is between $10-50 \mathrm{~g} / \mathrm{m}^{3}$ [13] and ignition sources can include sparks from mechanical/electrical equipment, or smoldering fires [14]. Since small biomass particles can become easily airborne when handled, dust clouds may form in the air of indoor storage spaces and ignite if in sufficient concentrations [12,14]. Furthermore, during the natural degradation of woody biomass, methane and carbon monoxide (both potentially explosive gases) are released. This consequently increases the risk of an explosion occurring especially in a confined space which is not properly ventilated. The lower explosive limit (LEL) for methane is $5 \%$ by volume, and $12 \%$ by volume for carbon monoxide [15].

Off-gassing from woody biomass storage is another hazard that has resulted in numerous fatalities, mainly from carbon monoxide poisoning and suffocation due to depleted oxygen environments [6]. Off-gassing is a process where carbon dioxide, carbon monoxide as well as volatile organic compounds (VOCs) are emitted as the lignocellulosic biomass undergoes biological degradation and chemical autoxidation [6,13]. Though it is well known that carbon monoxide is produced during the thermal anaerobic degradation of wood (pyrolysis), the chemical mechanism by which carbon monoxide is 
emitted from woody biomass at lower temperatures $\left(<100{ }^{\circ} \mathrm{C}\right)$ remains uncertain. It is postulated however that under these low temperature conditions, carbon monoxide is formed during the autoxidative degradation of fats and fatty acids, as well as through anaerobic biological digestion of the woody material [16]. Increased $\mathrm{CO}$ and $\mathrm{CO}_{2}$ concentrations in confined spaces can result in asphyxiation not only due to lower oxygen levels but also because of carbon monoxide's ability to prevent hemoglobin in the blood from binding to available oxygen (carbon monoxide has a 245 times stronger chemical affinity to hemoglobin than oxygen) $[13,17]$. In closed biomass storage facilities, these gasses can concentrate to levels in excess of the maximum government specified limits and have sudden detrimental effects on workers in this environment [13]. The US Occupational Safety and Health Administration (OSHA) defines 'oxygen deficient' as any atmosphere that contains less than 19.5\% oxygen [18] and the Approved Code of Practice (ACOP) to the Confined Space Regulations (1997) states that very low oxygen concentrations (below 16\%) can lead to unconsciousness and death [19]. The US National Institute for Occupational Safety and Health (NIOSH) has defined IDLH (Immediately Dangerous to Life or Health) values of 1200 ppm for carbon monoxide and 40,000 ppm (4\%) for carbon dioxide, not taking into consideration that simultaneous exposure to an oxygen deficient atmosphere further increases the risk of asphyxiation [20]. Aside from the non-condensable gases $\mathrm{CO}$ and $\mathrm{CO}_{2}$, the thermochemical conversion of the lipophilic compounds (fatty acids and resins) in wood can yield VOC's (such as aldehydes, ketones and complex terpenes), which may not necessarily result in such severe cases of rapid asphyxiation but can still have negative impacts on human health from exposure (e.g., irritation of the eyes and upper airways) [13].

Lastly, exposure to excessive amounts of dust particles and biological materials released from stored woody biomass can result in dermatitis, allergy development as well as cause irritation of the lungs and nasal passages, respiratory illness, along with carcinogenic effects [6,21]. Much of the biological material released into the air of biomass storage sites may be similar to the allergens and substances in the everyday air but are present in higher concentrations. The inhalation of these microbial spores, cells, or fragments can lead to serious allergic reactions or pulmonary diseases [6]. Furthermore, many of the fungi, actinomycetes and other bacteria present on wood chips, can be potentially pathogenic or toxigenic [8]. For example, exposure to the fungus Aspergillus fumigatus can lead to health complications for biomass handlers such as development of Aspergillosis or other Occupational Hypersensitivity Diseases (OHD) which often affect the lungs [8,22]. Even though processing in facilities may provide sufficient heat treatments that can kill and weaken the risks from most non-sporing pathogens, storage of organic matter may still allow microbes to grow at mesophilic temperatures $\left(\sim 20-45^{\circ} \mathrm{C}\right)$ and cases have existed where feedstock contained bacteria with the ability to produce heat-resistant spores (e.g., Clostridium botulinum) [13].

Due to the potential severity of risks associated with woody biomass storage and its handling, it is important to observe incident trends over time in order to identify hazardous practices, improve workplace conditions and to develop guidelines for the minimization of health and safety risks moving forward. This study attempts to quantify and evaluate major incident reports between 2000-2018 related to the hazards specifically associated with woody biomass storage. Furthermore, this study assesses the use of real-time biomass temperature monitoring for reducing the threat of self-heating and spontaneous ignition fires in biomass piles. To manage the high risks associated with these events, a system for real-time monitoring of internal pile temperature was investigated.

The overall purpose of this study was to analyse the prominent hazards associated with the storage of woody biomass in recent years and to highlight priorities for risk reduction. This article is intended to promote worker safety and accident avoidance, bring forward a possible solution for the real-time temperature monitoring of biomass piles, as well as bring attention to the need for further development of biomass storage guidelines and improved incident reporting. 


\section{Materials and Methods}

\subsection{Biomass Storage Incident Analysis}

A compilation of major incidents related to solid biofuels (dust explosions, self-heating fires, off-gassing, and biological hazards) between 2000 and February 2018 was prepared. Solid biofuels included only woody feedstocks such as wood chips, bark, wood pellets, and sawdust. Any issues arising from the storage of liquid and gaseous biofuels (e.g., explosions related to stored combustible gasses) were not included in this study. News articles, reports and review papers containing accounts of health and safety incidents were collected using online searches for key words such as "biomass", "storage", "facility", "self-heating", "combustion", and "self-ignition" in the same search as the words "accident," "incident", "explosion", "fire", "asphyxiation", and "off-gassing". Using the keywords, thorough searches were conducted using Google, Web of Science, University of Toronto online library search engines, as well as reputable bioenergy industry sites, incident watchdog sites, biomass magazines and journals including Canadian Biomass Magazine, OSHA database, IChemE database, 'Analysis, Research and Information on Accidents (ARIA)' database, Advanced Biomass, 'csb.gov', Work Safe BC, Wood Pellet Association of Canada, Canadian Forest Industries, Pulp \& Paper Canada, 'biofuelwatch.org', and The Biomass Monitor ('thebiomassmonitor.org').

The incidents were compiled into a database and categorised by incident type: "dust explosion", "self-heating", "off-gassing", "biological hazard" and "uncertain cause fire". Any biomass storage fire incident where it was stated that the source of fire was "unknown" or which did not explicitly state the source of the fire was a dust explosion or self-heating fire was classified as "uncertain cause". Other information recorded in the compiled incident database included date of occurrence, location of facility and a general description of the incident, injuries and damages (depending on available details). The number of reported incidents (and specific incident type) were totalled for each year and a distribution bar graph as well as temporal frequency distribution graphs were generated to observe trends in the compiled incident report data. The regional distribution of incidents was also considered, and a comparison table was prepared.

A Time Series Analysis using R Language was performed to forecast trend lines based on the biomass storage incident data over time (Table A2). Only incidents from the year 2000 to the end of 2017 were included in the analysis since 2018 data was incomplete (the incident data search was limited to February 2018). Holt's Exponential Smoothing Method [23-25] was used to estimate future trends (without seasonality) using the collected data and distribution plots of forecast errors were checked to ensure normality with means close to zero. ACF Plots for residuals at lags 1-20 were completed along with Ljung-Box tests to ensure the accuracy of the model. Holt-Winter Forecast Plots (with 2018-2028 forecasts) were displayed for each incident category along with the Ljung-Box test results.

\subsection{Real-Time Pile Monitoring}

Pineland Nurseries, Hadashville, Manitoba was selected as the long-term biomass storage site for a real-time biomass pile temperature monitoring field trial. Piles of fresh biomass (chipped within a week of pile assembly) and old biomass (stored in a large pile for over 1 year) were assembled on site (Figure A1). The fresh pile consisted primarily of poplar chips (from Sandilands Provincial Forest produced during the week of 14 August 2017). The old pile contained a mixture of primarily poplar chips with smaller amounts of spruce, balsam fir and white birch (sourced from Northwest Angle Provincial Forest between November and December 2015). A system was supplied by Braingrid Corporation, Toronto, ON, Canada for monitoring internal pile temperature on a real-time basis. The Braingrid sensor was located approximately $1 \mathrm{~m}$ from the top of the pile (Figure A2). For verification of the Braingrid sensor data, Tinytag thermologgers were buried within the piles, $1 \mathrm{~m}$ from top. Preliminary monitoring took place between 24 August 2017 and 10 September 2017 at which time Tinytag thermologgers were removed in order to retrieve the temperature data. Daily average temperatures were calculated for each pile using temperature readings (one reading every two hours) 
from the Tinytag thermologgers. Daily temperature readings from the Braingrid sensors (instantaneous at the time of measurement) were similarly recorded for both fresh and old biomass piles. The daily average pile temperature values from the retrieved Tinytag thermologgers were then plotted against the daily temperature readings from the Briangrid sensors in Excel (18 data points for each pile) in order to verify the accuracy of the Braingrid sensor data.

\section{Results}

\subsection{Biomass Storage Incident Analysis}

A compilation of incidents related to woody biomass storage from online searches is presented in Table A1 and a breakdown of dust explosion, self-heating, off-gassing and uncertain cause (fire) incidents can be found in Table A2. The regional distribution of incident occurrences can be found in Table A3. Biological hazard incidents were not included in the charts since no reported incidents could be directly related to the storage of woody biomass. Figure 1 displays self-heating and fires of uncertain origin as being the two most prominent biomass related storage incidents from 2000-2018 based on available reports from online searches. This is very closely followed by dust explosions, with off-gassing incident reports being the least prominent. In Figure $2 \mathrm{a}$, an overall increasing trend can be observed with reported biomass storage incidents after 2010, with the highest number of incidents reported in 2015 and 2017.

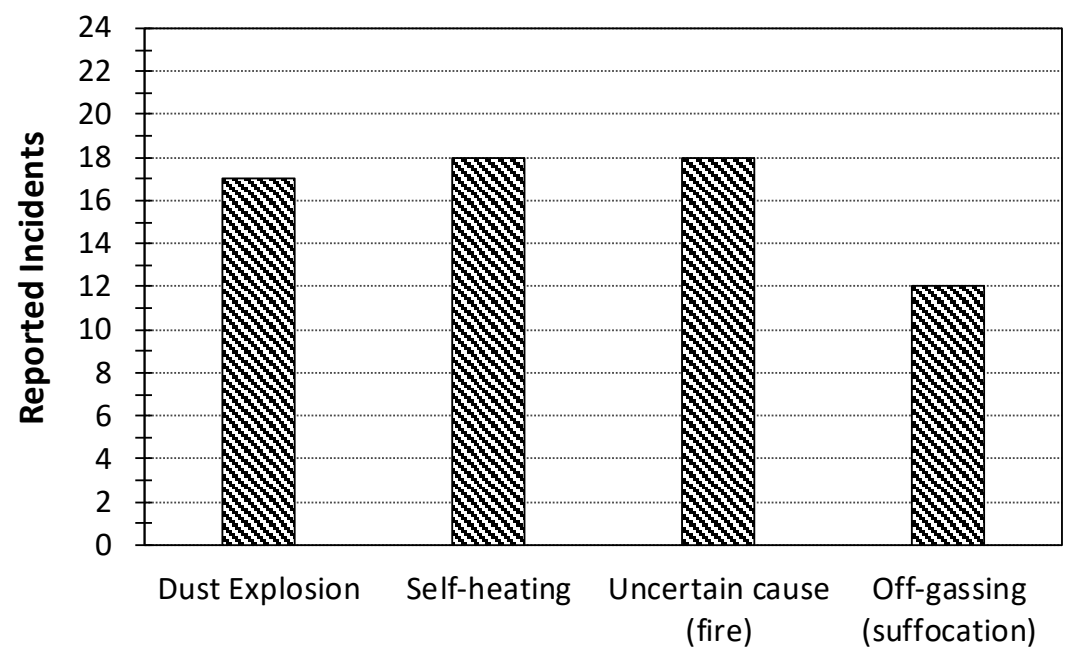

Biomass Storage Incident Description

Figure 1. Comparison of total biomass storage related incident reports (2000-February 2018) from online keyword searches. 


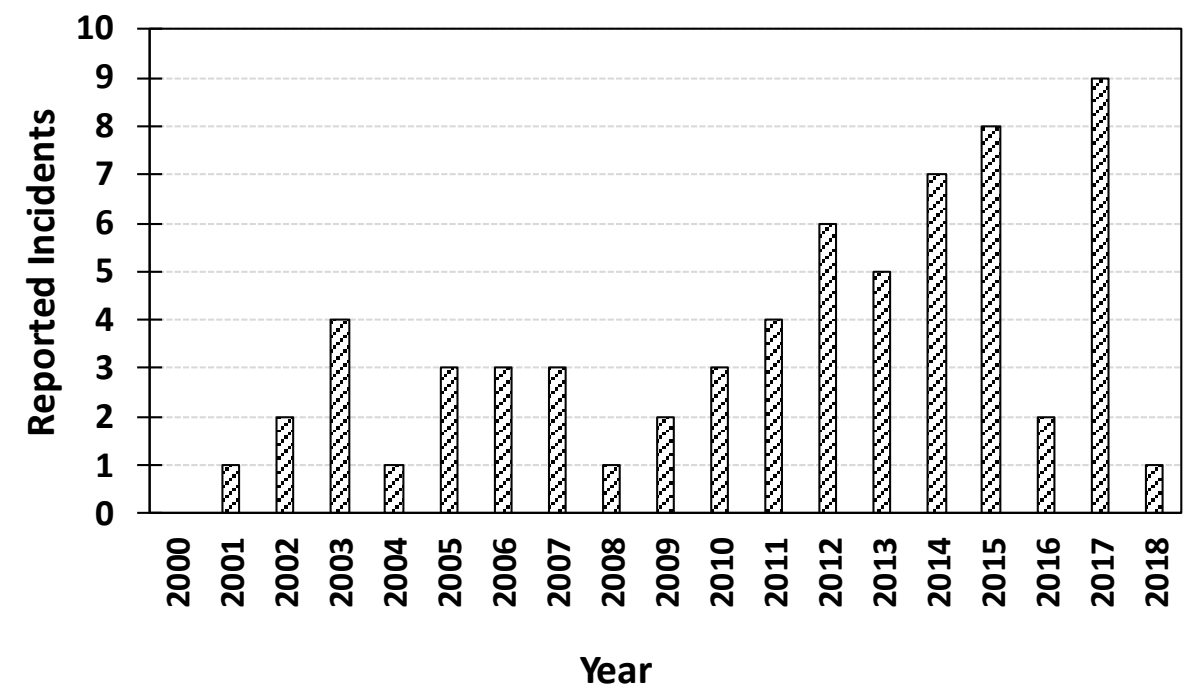

(a)

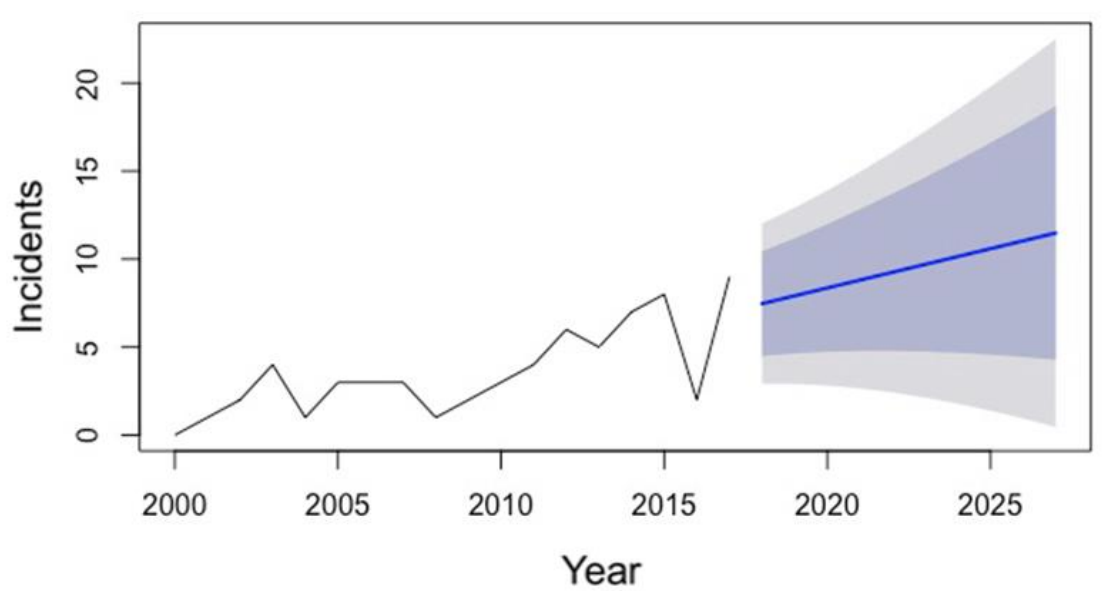

(b)

Figure 2. (a) Frequency of total reported biomass storage incident reports (2000-February 2018). (b) Holt-Winters forecast plot of total reported biomass storage incidents displaying the 2018-2028 forecasts (blue line), 80\% prediction interval (blue shaded area), and 95\% prediction interval (grey shaded area). Ljung-Box test $p$-value $=0.36$.

The number of reported self-heating incidents (Figure 3a) have increased greatly in the last 6 years, with the most reported incidents falling between 2015 and 2017. Reported incidents were lowest during 2000-2011, with several gap years reporting no notable incidents. Reports dealing with fires of uncertain causes during woody biomass storage (Figure 4a) displayed a sharp increase following 2014, peaking in 2017 (5 incidents) and 2015 (3 incidents). From 2000 to 2014 however, there were infrequent occurrences of 1 incident report per year and several years with no 'uncertain cause' incidents. A similar initial trend was observed for dust explosions (Figure 5a) with a lower frequency of incidents between 2000 and 2011 followed by an increase in the number of incidents, peaking in 2013. Following 2014 however, there appeared to be a significant drop in dust explosion reports with no reported incidents in 2016 or 2017. Finally, most off-gassing incident reports (Figure 6a) appeared to fall within 2005-2011 (2 incidents per year maximum in 2006, 2007 and 2010) with no major online reports of off-gassing from biomass storage between 2012 and February 2018.

The resulting biomass storage incident forecasts (2018-2028) obtained through Holt-Winter time series analysis confirmed the increasing trend of total biomass storage incident reports, self-heating 
and uncertain cause fires (Figure $2 b$, Figure $3 b$, and Figure $4 b$ respectively), the decreasing trend of dust explosion incident reports (Figure $5 b$ ), as well as the stable trend of off-gassing reports at zero (Figure 6b). Furthermore, the $p$-values obtained from the Ljung-Box tests were all found to be equal or greater than the confidence interval $(p>0.05)$ indicating that there was little evidence of non-zero autocorrelations in the in-sample forecast errors at lags 1-20. Table A3 reveals that the majority of reported incidents in this study took place in North America and Europe, with most off-gassing incidents occurring in Europe and Scandinavia.

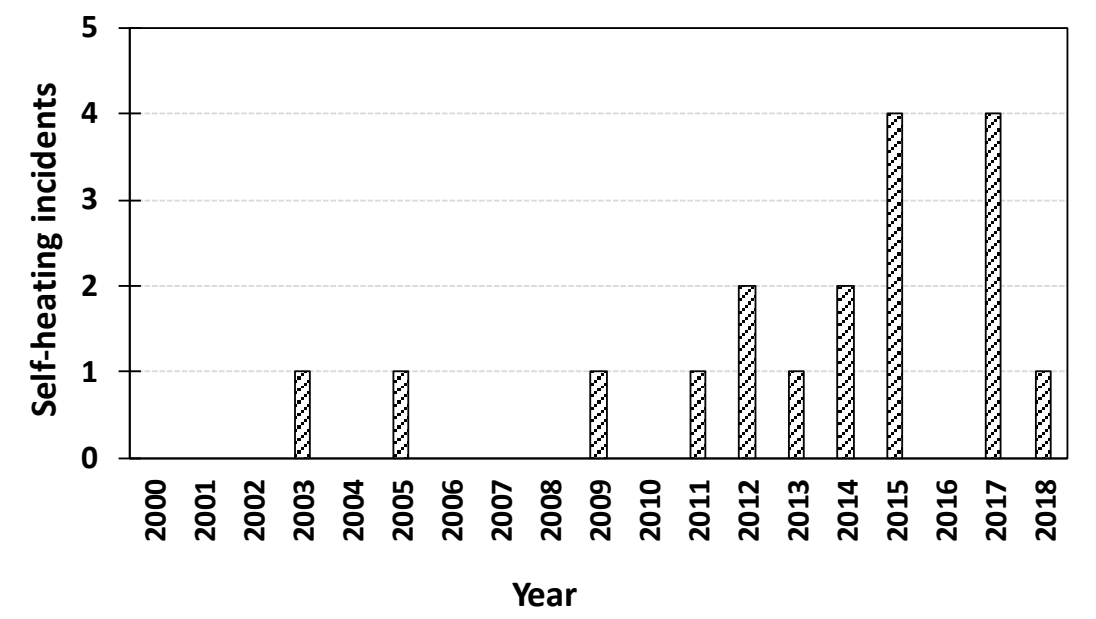

(a)

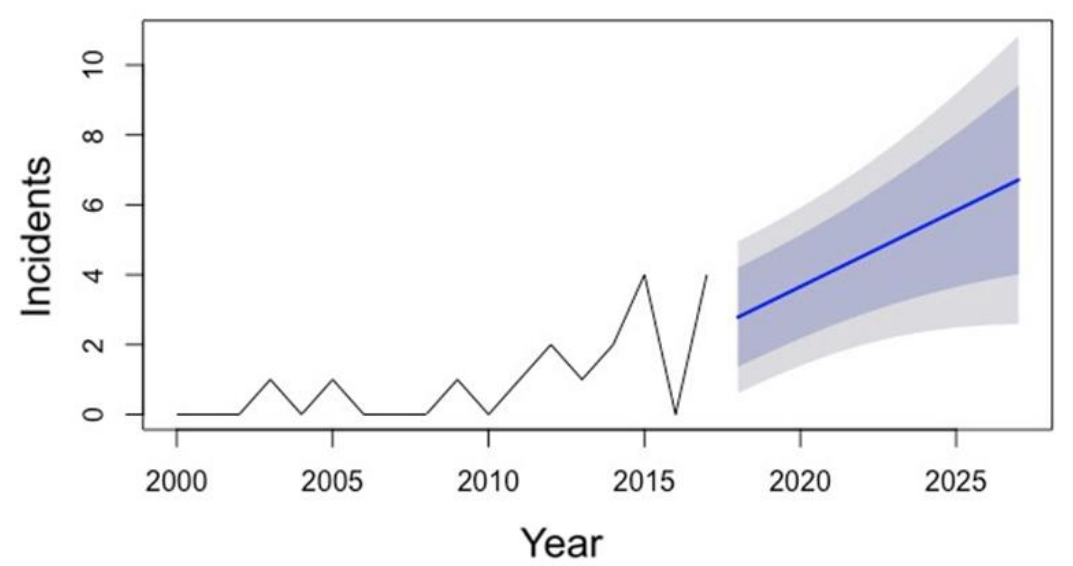

(b)

Figure 3. (a) Self-heating incident reports (2000-February 2018). (b) Holt-Winters forecast plot of self-heating incident reports displaying the 2018-2028 forecasts (blue line), $80 \%$ prediction interval (blue shaded area), and 95\% prediction interval (grey shaded area). Ljung-Box test $p$-value $=0.05$. 


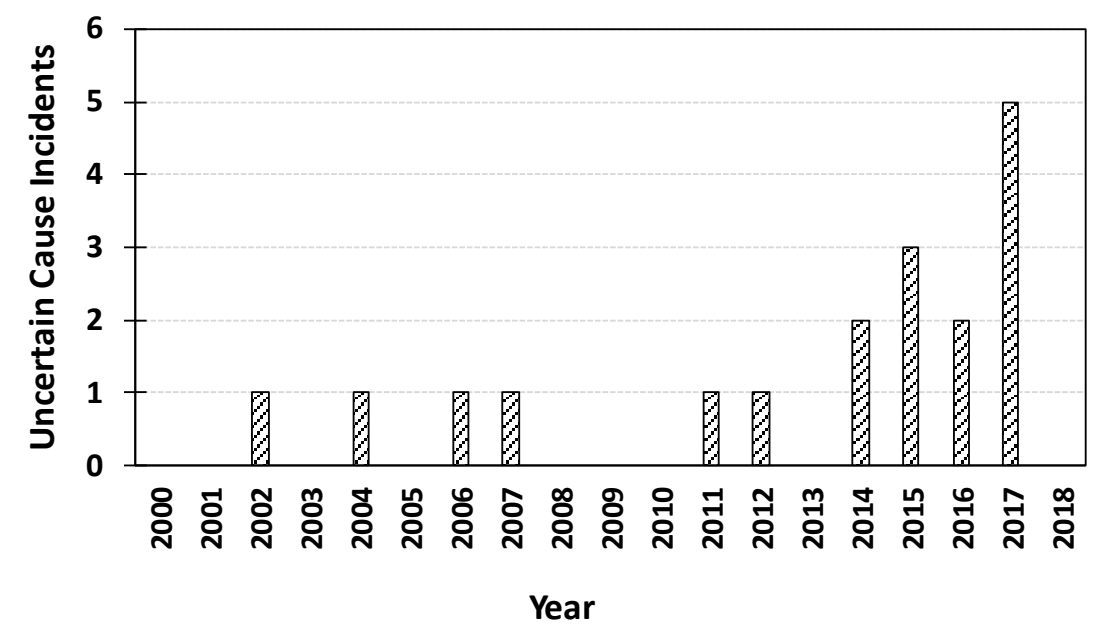

(a)

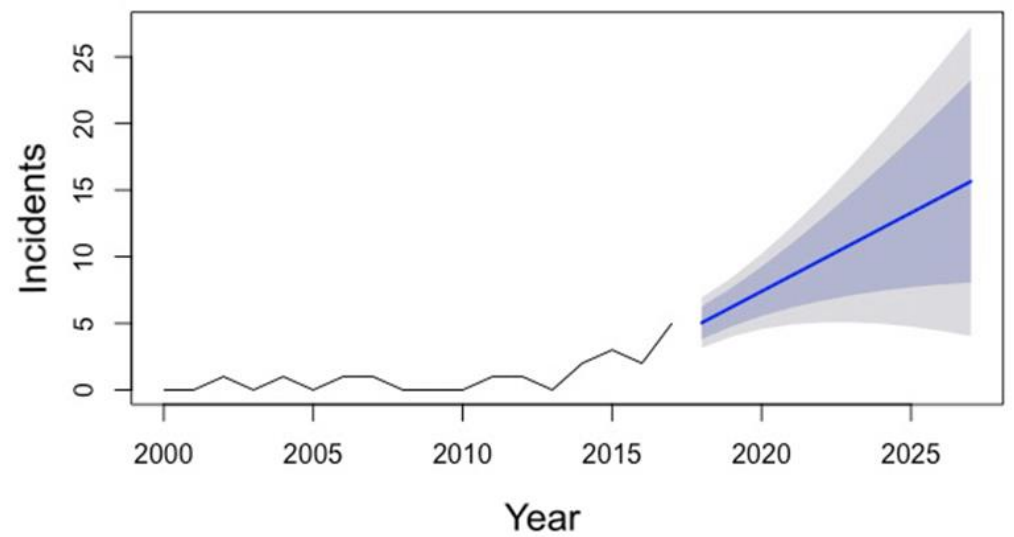

(b)

Figure 4. (a) Uncertain cause fire incident reports (2000-February 2018). (b) Holt-Winters forecast plot of uncertain cause fire incident reports displaying the 2018-2028 forecasts (blue line), 80\% prediction interval (blue shaded area), and 95\% prediction interval (grey shaded area). Ljung-Box test $p$-value $=0.30$. 


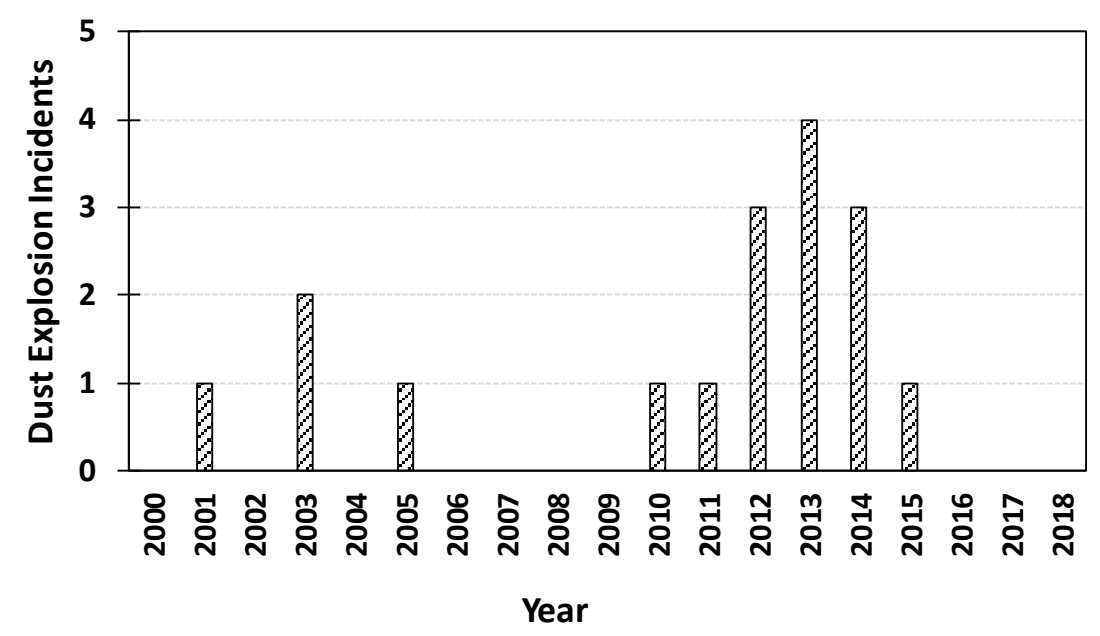

(a)

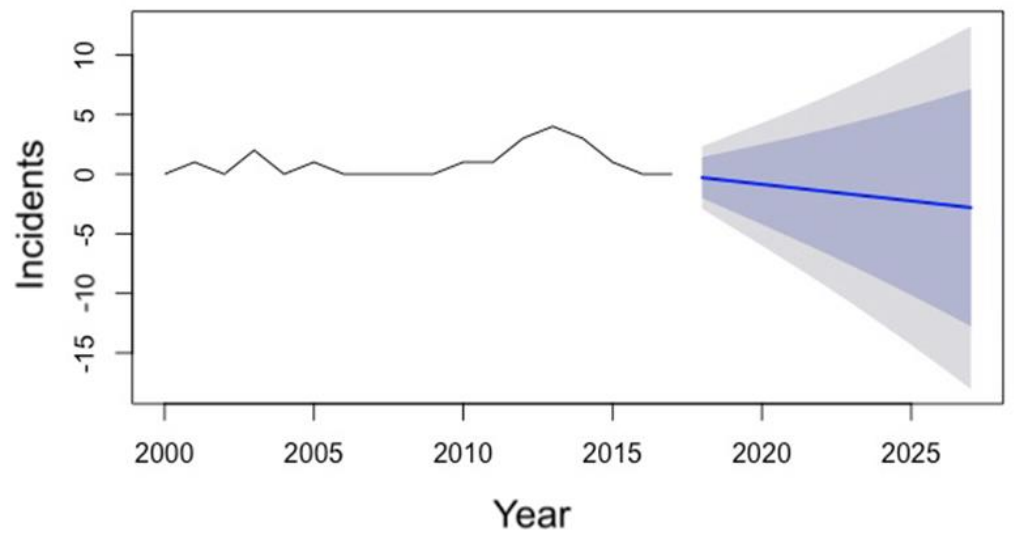

(b)

Figure 5. (a) Dust explosion incident reports (2000-February 2018). (b) Holt-Winters forecast plot of dust explosion incident reports displaying the 2018-2028 forecasts (blue line), $80 \%$ prediction interval (blue shaded area), and 95\% prediction interval (grey shaded area). Ljung-Box test $p$-value $=0.60$. 


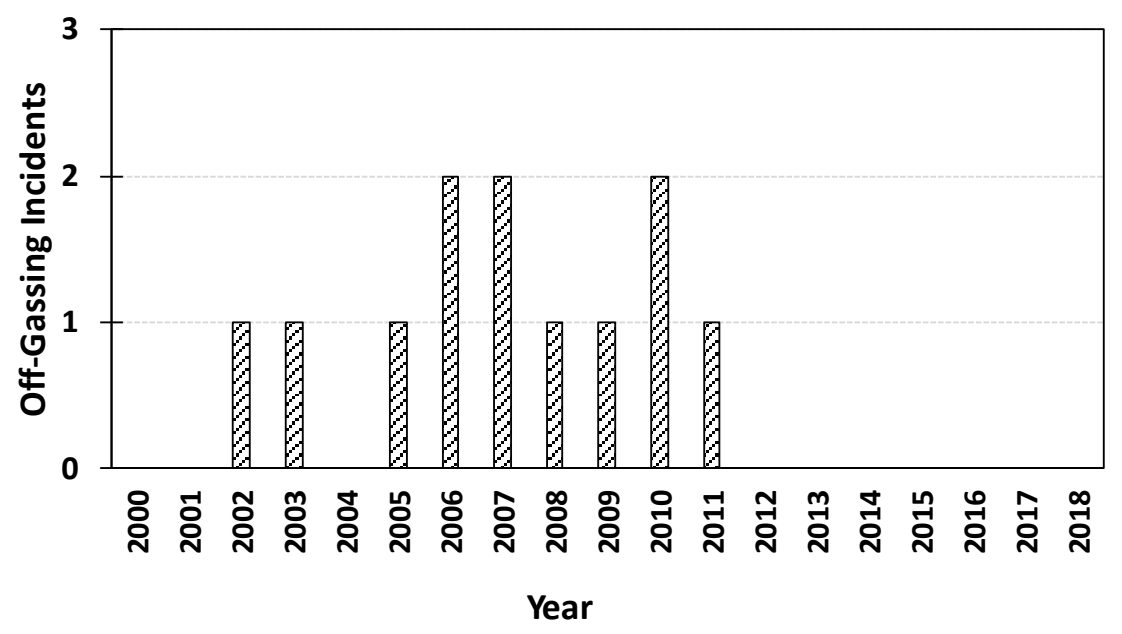

(a)

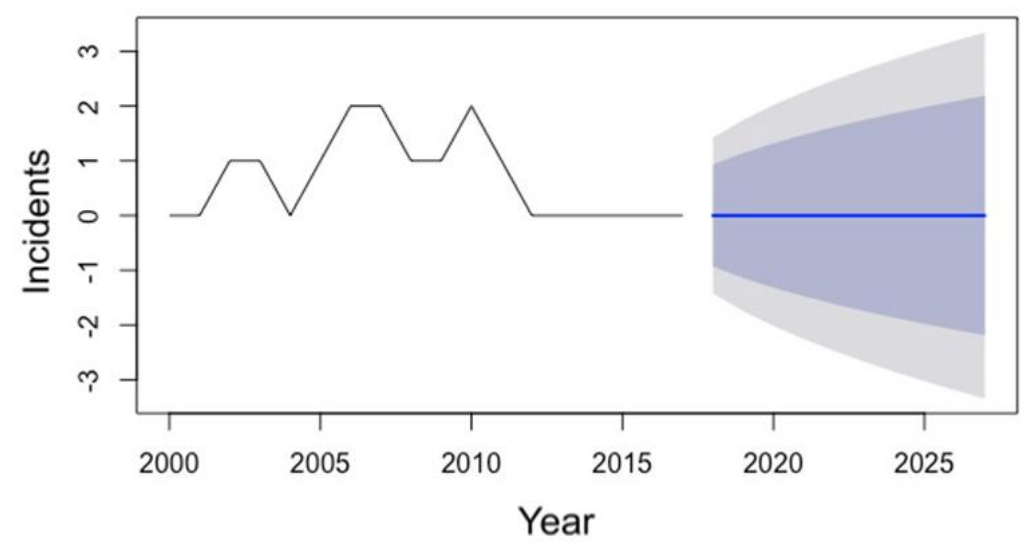

(b)

Figure 6. (a) Off-gassing incident reports (2000-February 2018). (b) Holt-Winters forecast plot of off-gassing incident reports displaying the 2018-2028 forecasts (blue line), 80\% prediction interval (blue shaded area), and 95\% prediction interval (grey shaded area). Ljung-Box test $p$-value $=0.57$.

\subsection{Real-Time Pile Temperature Monitoring}

Figures 7 and 8 are scatter plots of the daily temperature readings reported by the Braingrid systems versus the daily average temperatures from the Tinytag thermologgers for the old and fresh biomass piles respectively. Figure 7 shows a strong linear correlation between the two sets of temperature data with an $\mathrm{R}$ square value of 0.91 , an offset of $8.8^{\circ} \mathrm{C}$ and a linear coefficient of 1.27. Figure 8 shows a weaker linear correlation with an $R$ square value of 0.52 , an offset of $8{ }^{\circ} \mathrm{C}$ and a linear coefficient of 0.77 . 


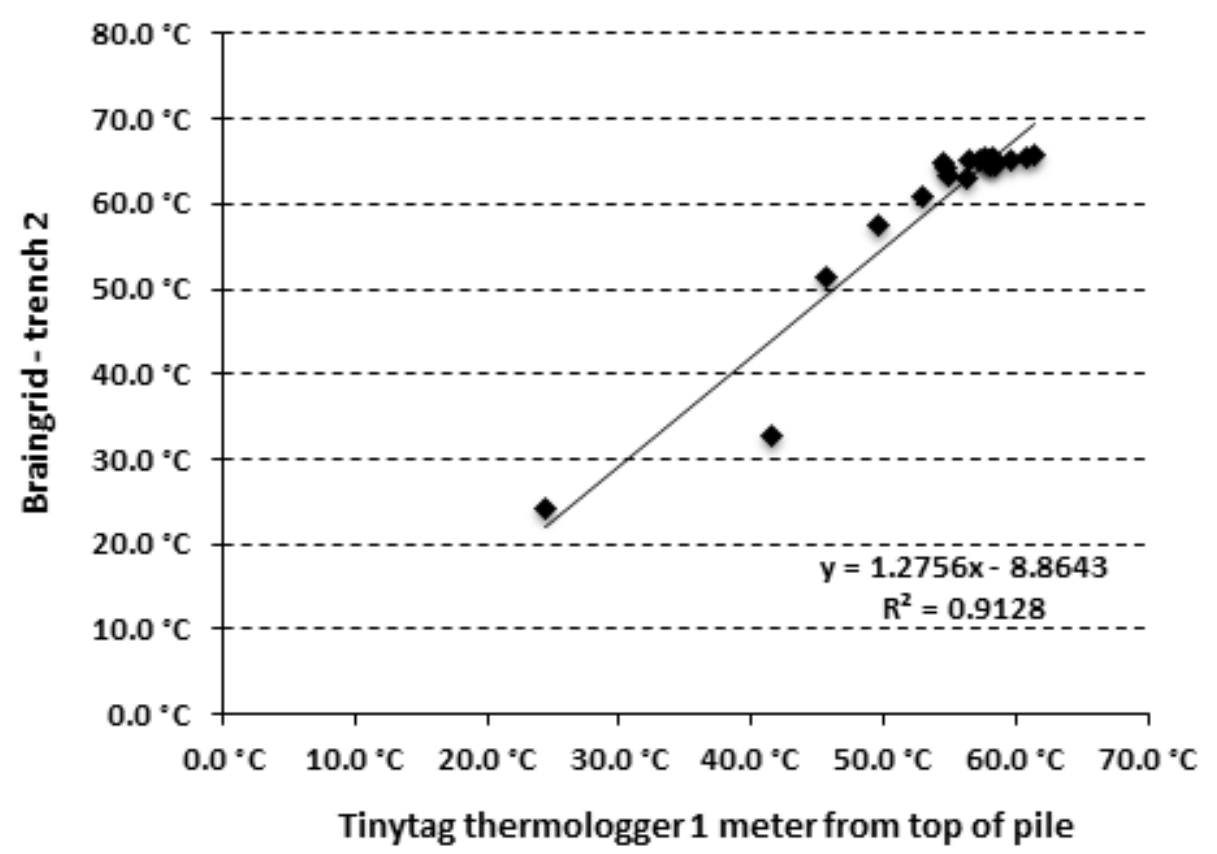

Figure 7. Old Pile: Correlation of temperature data as reported from the Braingrid sensor readings and Tinytag thermologger data.

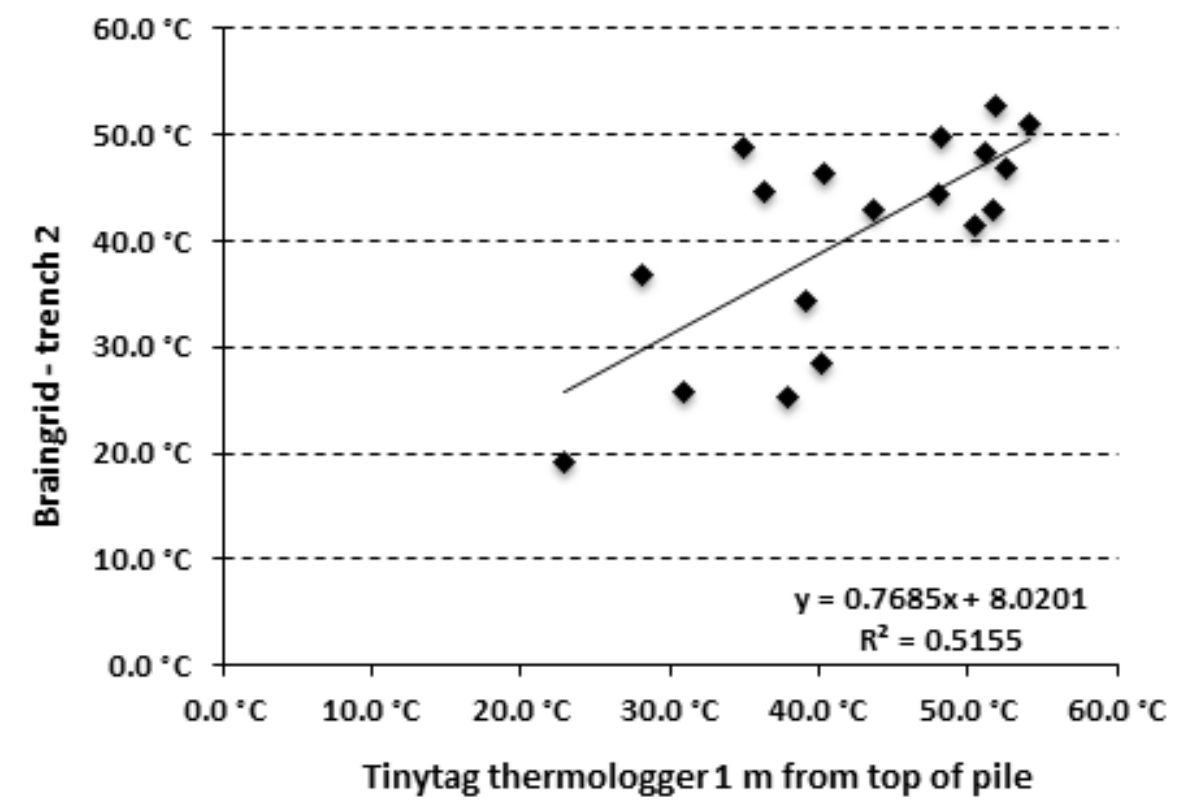

Figure 8. Fresh Pile: Correlation of temperature data as reported from the Braingrid sensor readings and Tinytag thermologger data.

\section{Discussion}

\subsection{Biomass Storage Incident Analysis}

The analysis of cumulative biomass storage incident reports demonstrated that there appears to be an overall increase in storage incidents occurring in recent years. This trend is in agreement with the study by Moreno and Cozzani (2015) who found that the overall number of major accidents in the bioenergy sector was increasing [3]. Similarly, in the report by Sovacool et al. (2015), a growing trend in accidents related to biomass was seen between 1990 and 2014 [2]. Out of the four categories of biomass 
storage related incident reports in this study (self heating, uncertain cause fires, dust explosions, and off-gassing), self-heating incidents appeared to be occurring more frequently in recent years (highest incident reports/year). This may be a result of greater biomass storage requirements with insufficient guidelines for self-heating prevention. The processes leading up to self-heating incidents are after all fairly complex (sources of heating include microbial cell respiration, thermochemical oxidation as well as heat-producing physical processes), thereby making predictive/prevention efforts difficult. This finding demonstrates that there is an urgency to understand how to best store woody biomass, taking into consideration the complex and dynamic mechanisms affecting the heating processes in biomass piles over time and under various conditions [5].

Analysis of reported incidents showed a spike in recent incidents where the cause of fire was uncertain (2015-2017) (Figure 4a). Often there is a lack of sufficient evidence which is required to properly classify the cause of a fire event. In a news article by Johnson (2013), an attorney, Daniel Hogan, said that many spontaneous combustion fires are classified as "undetermined causes" by fire marshals, because the ignition source cannot be found on site [26]. It is important to note that since the cause of fire in these reports are uncertain, there are many possibilities with regard to the source of ignition which may have been related to self-heating, equipment overheating during transfer (such as on conveyor belts), dust/gas combustion, or even vandalism. Many news articles lack in-depth details or updates on the fire investigations, mainly focusing on the severity and impact of the event. Without knowledge of root-cause however, it becomes very difficult to propose corrective actions and formulate preventative guidelines. The increasing trend of fires of uncertain causes in recent years highlights a need for more detailed and comprehensive fire investigations in the bioenergy industry. Information such as wood species, wood chip/pellet size, length of storage, geometry of storage pile and worker accounts leading up to the event can lead to better predictability of incidents followed by development of safe storage guidelines.

The decrease of dust explosion event reports observed following 2014-2015 is a positive trend that may be related to the increased safety awareness following the substantial number of events between 2012-2014, including two devastating explosions in British Columbia in 2012 which led to 4 fatalities and many injuries [27,28]. For example, on 26 April 2012, a directive order from WorkSafeBC was given to all 173 sawmills in British Columbia for the development of a dust control program including hazard and potential ignition source identification, risk assessment, worker education and training [29]. Similarly, the decrease in off-gassing events observed after 2011 is likely attributed to the severity of past incidents which surely increased industry awareness. Out of the 12 off-gassing incident reports included in this study, each one resulted in at least one fatality. According to Koppejan et al. (2013), the safety aspects of off-gassing went ignored for years until the fatal accidents in Rotterdam and Helsingborg [30] which led to in-depth investigations into the properties of wood pellets, handling guidelines and material safety data sheets $[13,31]$. Studies such as the review on carbon monoxide poisoning in pellet storerooms by Gauthier et al. (2012) further analysed such incidents and reported the need for improved monitoring, ventilation, warning signs and worker hazard awareness [32]. Simpson, Hemingway and Seymour (2016) studied several wood chip and wood pellet storage sites in the UK to assess risk management and safety awareness finding that off-gassing hazard awareness was limited at the small-scale work sites, but greater at the larger site studied [33]. This indicates that increased efforts will especially be needed for smaller biomass storage operations to raise hazard awareness. Throughout this research, the lack of biological hazard reports related to biomass storage became very apparent. Though it is known that increased exposure to wood dust can be hazardous, it is likely that many minor symptoms go unnoticed by biomass handlers and any long-term health effects experienced would not easily be traced back to the direct handling or exposure. Furthermore, symptoms such as difficulty breathing can be caused by a variety of factors (e.g., smoking and unrelated allergies) and it can therefore be difficult to solely attribute these symptoms to working around woody biomass. 
Though definite trends can be observed using available online accident reports, there are several limitations to this study which must be acknowledged. This study relied on incident report data from online sources with an understanding that this is not equivalent to the total number of incidents occurring. For an incident to be reported (especially in the media), it is assumed that the event itself must have been significant enough to report. The willingness of companies to disclose all accidents to the public, lack of media coverage and negligence of workers reporting past hazardous incidents are other factors which limit data availability. In the study by Koppejan et al. (2013), informal interviews of workers at various wood pellet plants were carried out. The series of interviews revealed that minor incidences involving dust explosions happen quite frequently, namely several times per year from their experience, and many of these explosions are often not reported to the authorities [13]. The occurrence of dust explosions was so commonplace to these workers that the handling of these incidents was in many cases considered part of their normal safety routine within the wood pellet plants [13]. This finding suggests that dust explosions (as well as the other incident types covered) are likely a larger issue in the biomass storage sector than might be indicated by the numbers in this report. The lack of hazardous accident accounting is sure to be commonplace and persist unless standardised reporting is used throughout the industry and up-to-date incident databases remain active/easily accessible.

Though the Holt-Winter time series analysis supported the forecasts generated from the incident data, the Ljung-Box test for self-heating incidents resulted in a $p$-value which was equivalent to the confidence interval limit $(p=0.05)$ (Figure $3 b)$. In this case, a weaker trendline was likely produced for self-heating compared to the other incident categories due to the absence of 2016 reports in combination with the high number of incident reports found for 2015 and 2017 (Figure 3a). Since a sudden fluctuation such as this would have decreased the reliability of the forecast, a larger sample size of incident data would be required for improving the temporal analysis. 10 years was chosen as a realistic forecast time due to the relatively small sample size.

A broader search criteria may have resulted in more incident data for improved forecast estimations, however it was reasoned that search limitations were necessary in order to ensure the accumulated data was as relative and reliable as possible. For example, only articles written in English were included in the online incident searches. Consequently, some international articles would have likely been overlooked since the keyword searches (e.g., "explosion") would need to be translated to search for media reports in other languages. To obtain a more reliable trend, this study only focussed on biomass storage incidents following the year 2000, since it was reasoned that there would be less online accounting of incidents previously and also that not all historic events would be made available online. Though cross-referencing was used when multiple articles describing the same incident were available, the statements made in the articles themselves were taken at face value and many could not be verified by a scholarly source. Furthermore, it was found that some of the news article links became invalid after some time and were no longer accessible online, as media sites (especially for overseas incidents) occasionally crash and links are discontinued. Despite these admitted shortcomings, this approach to reviewing incidents has been used successfully by other peer-reviewed studies [2,3].

\subsection{Real-Time Pile Monitoring}

The biomass storage incident analysis highlighted self-heating fires and fires of uncertain causes as prominent dangers which continue to pose a threat where large-scale biomass storage is required. The real-time temperature monitoring of biomass piles performed in this study demonstrates the value of this technology where large temperature fluctuations can be tracked for improved pile management. From the data of the two sensors (Braingrid and Tinytag Thermologgers) in Figures 7 and 8, there is a good correlation between the two measurement systems with an $\mathrm{R}^{2}$ of 0.91 for the old pile and 0.52 for the fresh pile. Since biomass pile temperatures are influenced by a number of localised variables including compaction and moisture content, it is improbable that the exact same temperature would be measured at various locations within the pile. This is likely one of the main reasons for the variations 
observed in the two sets of data (Figure 8). Though this was a preliminary trial, the resulting data confirms that real-time monitoring of the temperature within biomass piles may have potential for averting spontaneous combustion and preventing catastrophic events. Having real-time information on the internal temperature of the pile would allow operators to thoughtfully handle piles where there are no external signs of self-heating and where a sudden influx of oxygen could result in spontaneous ignition. Real-time temperature data acquired from these monitoring techniques may also be especially useful for improving self-heating and biomass degradation models $[7,34]$ which would certainly assist with furthering our understanding of pile dynamics for a variety of biomass feedstocks $[35,36]$. Furthermore, improved storage guidelines based on model optimization would ideally reduce any need for fixed detection-based monitoring systems [37] for the prevention of self-heating incidents in the future. Since the real-time monitoring trials are on-going, improved pile management techniques will surely become more apparent as data is collected over an extended time period.

The increasing trend of incident reports associated with the storage of woody biomass is an indication that there remains a need not only to increase preparedness for such hazards, but to obtain a better understanding of the dynamics of the events which lead to fires, dust explosions and health hazards in order to prevent these incidents from occurring. Frequently the designs of biomass storage facilities lean towards the most cost-effective design, without sufficiently looking at the resulting risks to safety [38]. Increased and constant worker awareness of potential hazards such as off-gassing in the workplace will be critical for maintaining health and safety. Effective hazard protocols should be set in place and practised in case of an emergency. Standardised monitoring guidelines for a variety of woody biomass types (woodchips, sawdust, bark, pellets) would be especially useful for preventing fires caused by self-heating. Lastly, improved accounting of such hazards and detailed collective incident databases related to woody biomass storage will strongly assist with preventing the frequency and intensity of future incidents.

\section{Conclusions}

The total number of woody biomass related accidents continues its increasing trend, especially with self-heating and fires of uncertain causes. Incident unpredictability and the complex nature of pile dynamics along with increased biomass storage needs in recent years both likely contributed to the apparent increase of such fire reports. Real-time pile monitoring appears to offer a viable solution for controlling such incidents by providing instant temperature data to pile managers. Furthermore, the accumulation of data from such monitoring techniques may be extremely useful for optimizing self-heating and biomass degradation models in the future. Aside from fire incidents, a decrease in dust explosions and off-gassing incident reports was found in this study. The low number of incidents in recent years is likely a result of increased awareness due to the severity of such accidents as well as improvements to risk assessment, worker awareness and training which inevitably followed major accidents in the past. Regardless of this apparent trend, diligence and caution must be maintained to uphold worker safety and hazard prevention. Along with further development of guidelines and monitoring pertaining to biomass storage, thorough incident investigations and detailed report databases will undeniably be required moving forward to decrease the risk of hazards as the bioenergy industry continues to expand.

Author Contributions: Conceptualization: S.K. and S.W.; Funding acquisition: S.W.; Supervision: S.K. and S.W.; Investigation: N.J. and C.H.; Writing (original draft): N.J. and C.H.; Visualization/Writing (review and editing): C.H., S.K. and S.V.e; Resources: S.M., J.A. and S.V.

Funding: This research was funded by Natural Resources Canada through the Energy Innovation Program (EIP).

Acknowledgments: The authors wish to acknowledge Gan Lin for his statistical analysis and assistance with assessing the incident trend data. The authors also wish to acknowledge David Flight for his assistance with the set-up and monitoring of the long-term storage trial at Pineland Forest.

Conflicts of Interest: The authors declare no conflict of interest. 


\section{Appendix A}

Table A1. Summary of biomass storage incident reports accumulated through online searches (2000-2018).

\begin{tabular}{|c|c|c|c|}
\hline $\begin{array}{l}\text { Reference \& } \\
\text { Incident Date }\end{array}$ & Category & Location & Description and Damages \\
\hline $\begin{array}{l}\text { [39] Incident: } 26 \\
\text { May } 2001 .\end{array}$ & $\begin{array}{l}\text { Dust } \\
\text { explosion }\end{array}$ & Gaylord, (USA) & $\begin{array}{l}\text { (26 May 2001) Following an explosion and fire at a press board } \\
\text { manufacturing plant the day before, firemen opened a silo to extinguish } \\
\text { burning wood chips. When firefighters opened the silo to pour water on } \\
\text { the flames, the sudden infusion of oxygen caused the second blast. One } \\
\text { firefighter was seriously burned and } 5 \text { were treated for smoke inhalation. }\end{array}$ \\
\hline $\begin{array}{l}\text { [40] Incident: } \\
2002 .\end{array}$ & $\begin{array}{l}\text { Uncertain } \\
\text { cause (fire) }\end{array}$ & $\begin{array}{l}\text { Athens, Maine } \\
\text { (USA) }\end{array}$ & $\begin{array}{l}\text { In 2002, a fire started in a smoldering fuel pile at the Boralex construction } \\
\text { and demolition debris incinerator. Several people were reportedly taken } \\
\text { to the hospital for smoke inhalation. }\end{array}$ \\
\hline $\begin{array}{l}\text { [30] Incident: } \\
\text { May } 2002 .\end{array}$ & $\begin{array}{l}\text { Off-gassing } \\
\text { (suffocation) }\end{array}$ & $\begin{array}{l}\text { Port of } \\
\text { Rotterdam, } \\
\text { Netherlands }\end{array}$ & $\begin{array}{l}\text { In May 2002, one worker died and several others were injured onboard a } \\
\text { ship from British Columbia (MV Weaver Arrow) due to the gas discharge } \\
\text { of pellets being stored in transport. }\end{array}$ \\
\hline $\begin{array}{l}\text { [41] Incident: } 28 \\
\text { March } 2003 .\end{array}$ & $\begin{array}{l}\text { Dust } \\
\text { explosion }\end{array}$ & $\begin{array}{l}\text { Bar Sur Aube, } \\
\text { France }\end{array}$ & $\begin{array}{l}\text { In a furniture factory, an explosion occurred inside a silo of wood chips } \\
\text { feeding the boiler. Minor damages with no reported injuries. }\end{array}$ \\
\hline $\begin{array}{l}\text { [42] Incident: } 7 \\
\text { May } 2003 .\end{array}$ & $\begin{array}{l}\text { Dust } \\
\text { explosion }\end{array}$ & Gaillon, France & $\begin{array}{l}\text { A deflagration occurred on a cyclone filter inside a sawmill/wood shop. } \\
\text { The fire engulfed } 500 \mathrm{~m}^{2} \text { of a production building roof and } 300 \mathrm{~m}^{2} \text { of roof } \\
\text { on a maintenance building. One person sustained skin burns on the } \\
\text { shoulders. }\end{array}$ \\
\hline $\begin{array}{l}\text { [43] Incident: } 6 \\
\text { October } 2003 .\end{array}$ & Self-heating & $\begin{array}{l}\text { Rambervillers, } \\
\text { France }\end{array}$ & $\begin{array}{l}\text { In a wood panel manufacturing plant, a fire broke out on a stock of } 1200 \\
\text { tons of chips. The accident was caused by the self-ignition of chips. No } \\
\text { reported injuries. }\end{array}$ \\
\hline $\begin{array}{l}\text { [32] Incident: } \\
2003 .\end{array}$ & Off-gassing & USA & $\begin{array}{l}\text { One death occurred in a cargo hold carrying timber due to off-gassing. } \\
\text { No further information available. }\end{array}$ \\
\hline $\begin{array}{l}\text { [44] Incident: } 15 \\
\text { April } 2004 .\end{array}$ & $\begin{array}{l}\text { Uncertain } \\
\text { cause (fire) }\end{array}$ & $\begin{array}{l}\text { Saint-Florentin, } \\
\text { France }\end{array}$ & $\begin{array}{l}\text { A fire broke out on a } 150 \mathrm{~m}^{3} \text { outdoor pile of untreated waste wood from a } \\
\text { planing workshop (when loading chippings into a semi-trailer). A } \\
\text { firefighter received minor burns to one hand during the intervention. }\end{array}$ \\
\hline [6] Incident: 2005. & $\begin{array}{l}\text { Off-gassing } \\
\text { (suffocation) }\end{array}$ & Gruvon, Sweden & $\begin{array}{l}\text { A seaman suffocated on the wood freighter "Eken" when he went down } \\
\text { the stairs to the cargo room which was filled with pulpwood. }\end{array}$ \\
\hline $\begin{array}{l}\text { [45] Incident: } 25 \\
\text { January } 2005 .\end{array}$ & $\begin{array}{l}\text { Dust } \\
\text { explosion }\end{array}$ & Corbenay, France & $\begin{array}{l}\text { A wood dust explosion occurred in a manufacturing plant in a } 360 \mathrm{~m}^{3} \\
\text { silo containing } 30 \mathrm{~m}^{3} \text { of dry chips. The accident occurred while the } \\
\text { reservoir was being emptied (just } 5 \text { days after an earlier fire at the site). } \\
\text { No reported injuries. }\end{array}$ \\
\hline $\begin{array}{l}\text { [46] Incident: } \\
\text { December } 2005 .\end{array}$ & Self-heating & $\begin{array}{l}\text { Southwestern } \\
\text { Ontario }\end{array}$ & $\begin{array}{l}\text { A large wood chip pile }\left(400^{\prime} \times 75^{\prime} \times 30^{\prime}\right) \text { being stored for a greenhouse } \\
\text { operation caught on fire (self-ignited). Two months later, another section } \\
\text { of the pile self-ignited. }\end{array}$ \\
\hline $\begin{array}{l}\text { [40] Incident: } \\
\text { October } 2006 .\end{array}$ & $\begin{array}{l}\text { Uncertain } \\
\text { cause (fire) }\end{array}$ & $\begin{array}{l}\text { Livermore Falls, } \\
\text { Maine (USA) }\end{array}$ & $\begin{array}{l}\text { In October 2006, a fuel pile caught fire at Beaver Wood Energy's biomass } \\
\text { power facility in Livermore Falls, Maine (and burned for over a month). }\end{array}$ \\
\hline $\begin{array}{l}\text { [30] Incident: } \\
\text { November } 2006 .\end{array}$ & $\begin{array}{l}\text { Off-gassing } \\
\text { (suffocation) }\end{array}$ & $\begin{array}{l}\text { Port of } \\
\text { Helsingborg, } \\
\text { Sweden }\end{array}$ & $\begin{array}{l}\text { In November 2006, one worker was killed, one seriously injured, and } \\
\text { several rescue workers were injured due to off gassing from biomass } \\
\text { storage in transport aboard the MS Saga Spray (from British Columbia). }\end{array}$ \\
\hline [6] Incident: 2006. & $\begin{array}{l}\text { Off-gassing } \\
\text { (suffocation) }\end{array}$ & $\begin{array}{l}\text { Skelleftehamn, } \\
\text { Sweden }\end{array}$ & $\begin{array}{l}\text { A seaman onboard the "Noren" died when he entered a storage } \\
\text { compartment filled with woodchips. }\end{array}$ \\
\hline $\begin{array}{l}\text { [40] Incident: } \\
\text { May } 2007 .\end{array}$ & $\begin{array}{l}\text { Uncertain } \\
\text { cause (fire) }\end{array}$ & $\begin{array}{l}\text { Sittard, } \\
\text { Netherlands }\end{array}$ & $\begin{array}{l}\text { An explosion occurred at a biomass energy facility in Sittard, } \\
\text { Netherlands on } 10 \text { May } 2007 .\end{array}$ \\
\hline [6] Incident: 2007. & $\begin{array}{l}\text { Off-gassing } \\
\text { (suffocation) }\end{array}$ & Timra, Sweden & $\begin{array}{l}\text { The captain and one seaman onboard the "Fembria" (wood-freighter) } \\
\text { died when they walked into a storage compartment filled with timber } \\
\text { wood. }\end{array}$ \\
\hline [6] Incident: 2007. & $\begin{array}{l}\text { Off-gassing } \\
\text { (suffocation) }\end{array}$ & Finland & A person died when walking into a 10 tonne wood pellet silo. \\
\hline [6] Incident: 2008. & $\begin{array}{l}\text { Off-gassing } \\
\text { (suffocation) }\end{array}$ & Finland & Another person died when walking into a 10 tonne wood pellet silo. \\
\hline $\begin{array}{l}\text { [40] Incident: } 4 \\
\text { July } 2009 .\end{array}$ & $\begin{array}{l}\text { Self-heating } \\
\text { (suspected) }\end{array}$ & $\begin{array}{l}\text { White City, } \\
\text { Oregon (USA) }\end{array}$ & $\begin{array}{l}\text { An } 80 \text {-foot-high biomass (woodchip) pile caught on fire at the Biomass } \\
\text { One power plant in White City, Oregon on } 4 \text { July 2009. No reported } \\
\text { injuries. }\end{array}$ \\
\hline [6] Incident: 2009. & $\begin{array}{l}\text { Off-gassing } \\
\text { (suffocation) }\end{array}$ & $\begin{array}{l}\text { Bornholm, } \\
\text { Denmark }\end{array}$ & $\begin{array}{l}\text { Two seamen died onboard the "Amirante" when they entered a cargo } \\
\text { room filled with wood pellets (pellets were loaded one day prior to the } \\
\text { incident). }\end{array}$ \\
\hline
\end{tabular}


Table A1. Cont.

\begin{tabular}{|c|c|c|c|}
\hline $\begin{array}{l}\text { Reference \& } \\
\text { Incident Date }\end{array}$ & Category & Location & Description and Damages \\
\hline $\begin{array}{l}\text { [47] Incident: } \\
\text { August } 2010 .\end{array}$ & $\begin{array}{l}\text { Dust } \\
\text { explosion }\end{array}$ & Marion, USA & $\begin{array}{l}\text { A fire blazed through AJ Stove \& Pellet plant } 2 \text { August } 2010 \text {. The fire } \\
\text { started in the plant's storage hopper by the back of the building. The } \\
\text { spark of the fire was a dust explosion. The business was shut down while } \\
\text { the owners made improvements. No injuries. }\end{array}$ \\
\hline $\begin{array}{l}\text { [6,30] Incident: } \\
\text { January } 2010 .\end{array}$ & $\begin{array}{l}\text { Off-gassing } \\
\text { (suffocation) }\end{array}$ & Germany & $\begin{array}{l}\text { A } 43 \text {-year-old engineer died in a small town in Germany after he opened } \\
\text { a pellet bunker door (storage room contained } 155 \text { tons of pellets). } \\
\text { A second worker who was standing right behind him was also affected } \\
\text { but still able to call the emergency services. }\end{array}$ \\
\hline $\begin{array}{l}\text { [6,30] Incident: } \\
\text { November } 2010 .\end{array}$ & $\begin{array}{l}\text { Off-gassing } \\
\text { (suffocation) }\end{array}$ & Ireland & $\begin{array}{l}\text { A 38-year-old man in Ireland died after entering the 7-tonne wood pellet } \\
\text { storage room. His wife and another man were treated in hospital after } \\
\text { trying to pull him to safety. }\end{array}$ \\
\hline $\begin{array}{l}\text { [48] Incident: } 21 \\
\text { June } 2011 .\end{array}$ & $\begin{array}{l}\text { Dust } \\
\text { explosion } \\
\text { (suspected) }\end{array}$ & $\begin{array}{l}\text { Waycross, } \\
\text { Georgia (USA) }\end{array}$ & $\begin{array}{l}\text { An explosion occurred in a biomass wood pellet processing plant near } \\
\text { Waycross on } 21 \text { June 2011, causing extensive damage to the processing } \\
\text { facility. No reported injuries. }\end{array}$ \\
\hline $\begin{array}{l}\text { [49] Incident: } \\
\text { October } 2011 .\end{array}$ & Self-heating & $\begin{array}{l}\text { South Shields, } \\
\text { UK }\end{array}$ & $\begin{array}{l}\text { A 200-tonne stockpile of biomass pellets is understood to have } \\
\text { spontaneously combusted within a concrete storage unit ( } 30 \text { October } \\
\text { 2011). Around } 25 \text { tonnes of wood had been burned in the fire, with } \\
\text { firefighters spending more than } 12 \text { hours battling the fire. No injuries. }\end{array}$ \\
\hline $\begin{array}{l}\text { [50] Incident: } 23 \\
\text { November } 2011\end{array}$ & $\begin{array}{l}\text { Uncertain } \\
\text { cause (fire) }\end{array}$ & $\begin{array}{l}\text { Nanton, Alberta } \\
\text { (Canada) }\end{array}$ & $\begin{array}{l}\text { A large wood chip pile caught fire at Chinook Feeders (Nanton, Alberta) } \\
\text { during a very high wind period (which fed the flames and spread the fire } \\
\text { in the surrounding area). No reported injuries. }\end{array}$ \\
\hline $\begin{array}{l}\text { [6,30] Incident: } \\
\text { February } 2011 .\end{array}$ & $\begin{array}{l}\text { Off-gassing } \\
\text { (suffocation) }\end{array}$ & Switzerland & $\begin{array}{l}\text { A 28-year-old woman who was four months pregnant was found dead } \\
\text { from suffocation in an } 82-\mathrm{m}^{3} \text { pellet storeroom. }\end{array}$ \\
\hline $\begin{array}{l}\text { [28] Incident: } \\
\text { January } 2012 .\end{array}$ & $\begin{array}{l}\text { Dust } \\
\text { explosion }\end{array}$ & $\begin{array}{l}\text { Burns Lake, } \\
\text { British Columbia }\end{array}$ & $\begin{array}{l}\text { Excessive wood dust led to an explosion which destroyed the Babine } \\
\text { Forest Products sawmill in Burns Lake, British Columbia on } 20 \text { January } \\
\text { 2012. Two workers were killed, and } 19 \text { others were injured. }\end{array}$ \\
\hline $\begin{array}{l}\text { [51] Incident: } 27 \\
\text { February } 2012 .\end{array}$ & $\begin{array}{l}\text { Self-heating } \\
\text { (suspected) }\end{array}$ & Essex, UK & $\begin{array}{l}\text { A very large fire burned inside the wood pellet silos of RWE's Tilbury } \\
\text { Power Station in Essex, UK on } 27 \text { February 2012. (Fire began in a wood } \\
\text { hopper; smoldering wood pellets were suspected of triggering the } \\
\text { dust fire). }\end{array}$ \\
\hline $\begin{array}{l}\text { [52] Incident: } 11 \\
\text { May } 2012 .\end{array}$ & $\begin{array}{l}\text { Dust } \\
\text { explosion }\end{array}$ & $\begin{array}{l}\text { Copenhagen, } \\
\text { Denmark }\end{array}$ & $\begin{array}{l}\text { A wood dust explosion occurred in a wood pellet silo at the Amager } \\
\text { Power Station in Copenhagen, Denmark on } 11 \text { May 2012. (Occurred } \\
\text { during "bang and clean" cleaning method). Three people were injured, } \\
\text { one with severe burns. }\end{array}$ \\
\hline $\begin{array}{l}\text { [53] Incident: } 17 \\
\text { December } 2012 .\end{array}$ & $\begin{array}{l}\text { Self-heating } \\
\text { (suspected) }\end{array}$ & $\begin{array}{l}\text { Copenhagen, } \\
\text { Denmark }\end{array}$ & $\begin{array}{l}\text { A fire started in a wood silo containing wood pellets at the Amager } \\
\text { Power station in Copenhagen on } 17 \text { December 2012. No reported injuries. }\end{array}$ \\
\hline $\begin{array}{l}\text { [27] Incident: } 24 \\
\text { April } 2012 .\end{array}$ & $\begin{array}{l}\text { Dust } \\
\text { explosion }\end{array}$ & $\begin{array}{l}\text { Prince George, } \\
\text { British Columbia }\end{array}$ & $\begin{array}{l}\text { A huge explosion and fire occurred at Lakeland Mills sawmill in Prince } \\
\text { George, BC on } 24 \text { April 2012. Two workers died, } 24 \text { were injured. }\end{array}$ \\
\hline $\begin{array}{l}\text { [54] Incident: } \\
2012 .\end{array}$ & $\begin{array}{l}\text { Uncertain } \\
\text { cause (fire) }\end{array}$ & $\begin{array}{l}\text { Upper Leacock } \\
\text { Township, (USA) }\end{array}$ & $\begin{array}{l}\text { A fire broke out in storage silos at the Ironstone Mills plant. The fire } \\
\text { began when two feet of sawdust left at the bottom of the silo had started } \\
\text { to smoulder. The loss in sawdust material was estimated to be worth } \\
\text { about } \$ 500 \text {. No injuries. }\end{array}$ \\
\hline $\begin{array}{l}\text { [55] Incident: } \\
2013 .\end{array}$ & $\begin{array}{l}\text { Dust } \\
\text { explosion }\end{array}$ & $\begin{array}{l}\text { East Providence, } \\
\text { (USA) }\end{array}$ & $\begin{array}{l}\text { A dust explosion and fire occurred at the Inferno Wood Pellets Company } \\
\text { facility. Notably, the owners had invested capital to bring the building up } \\
\text { to code and even received a license to operate the facility. One worker } \\
\text { was injured. }\end{array}$ \\
\hline $\begin{array}{l}\text { [56] Incident: } \\
2013 .\end{array}$ & $\begin{array}{l}\text { Dust } \\
\text { explosion }\end{array}$ & $\begin{array}{l}\text { Kimball Place, } \\
\text { (USA) }\end{array}$ & $\begin{array}{l}\text { The explosion and fire broke out at the Creative Biomass plant. The fire } \\
\text { activated the sprinkler systems in the single storey part of the old grain } \\
\text { mill, and another fire broke out at another six-storey part of the building. } \\
\text { Initial investigations believe that the dust collection system } \\
\text { malfunctioned. No injuries. }\end{array}$ \\
\hline $\begin{array}{l}\text { [57] Incident: } \\
2013 .\end{array}$ & $\begin{array}{l}\text { Dust } \\
\text { explosion }\end{array}$ & Woodville, USA & $\begin{array}{l}\text { A dust explosion took place at a German Pellet plant in } 2013 \text {. The } \\
\text { explosion occurred in one of the silos which subsequently caused a fire to } \\
\text { break out into another silo. The plant production capacity was listed as } \\
578,000 \text { metric tons of pellets per year. No injuries. }\end{array}$ \\
\hline $\begin{array}{l}\text { [58] Incident: } \\
2013 .\end{array}$ & $\begin{array}{l}\text { Dust } \\
\text { explosion }\end{array}$ & $\begin{array}{l}\text { Taupo, New } \\
\text { Zealand }\end{array}$ & $\begin{array}{l}\text { A dust explosion (sawdust) occurred at a Rotokawa wood pellet plant. } \\
\text { The explosion started in the silo and ducting of the facility. The result of } \\
\text { the fire did not cause any physical damage to the building itself, though } \\
\text { it had to be put out of commission for several days. No injuries. }\end{array}$ \\
\hline $\begin{array}{l}\text { [59] Incident: } \\
2013 \text {. }\end{array}$ & $\begin{array}{l}\text { Self-heating } \\
\text { (suspected) }\end{array}$ & Shakopee, USA & $\begin{array}{l}\text { A fire broke out in two of the fuel storage silos at the Koda } \\
\text { combined-heat-and-power biomass facility (2013). The } 23.4 \text { MW facility } \\
\text { burns wood chips, oat hulls and other organic materials to generate } \\
\text { electricity for Xcel Energy Inc. The fire burned for over a week and } \\
\text { damaged a conveyor belt and a truck unloading facility. No injuries. }\end{array}$ \\
\hline
\end{tabular}


Table A1. Cont.

\begin{tabular}{|c|c|c|c|}
\hline $\begin{array}{l}\text { Reference \& } \\
\text { Incident Date }\end{array}$ & Category & Location & Description and Damages \\
\hline $\begin{array}{l}\text { [60] Incident: } \\
2014 .\end{array}$ & Self-heating & Ilkeston, England & $\begin{array}{l}\text { A fire broke out at the Arcwood Recycling facility in a pile of } 8000 \text { tonnes } \\
\text { of stored wood. Investigations determined that the wood was stored too } \\
\text { close to a gas supply, suggesting non-compliance with regulations. As a } \\
\text { result, the owner of the facility pleaded guilty to safety failures. } \\
\text { No injuries. }\end{array}$ \\
\hline $\begin{array}{l}\text { [61] Incident: } 29 \\
\text { April } 2014 .\end{array}$ & $\begin{array}{l}\text { Dust } \\
\text { explosion }\end{array}$ & Moray, Scotland & $\begin{array}{l}\text { Seven people (including firefighters) were injured in a fire and explosion } \\
\text { at an industrial estate in Moray, Scotland. The incident involved a wood } \\
\text { dust silo bin, in which the company burned excess sawdust. }\end{array}$ \\
\hline $\begin{array}{l}\text { [62] Incident: } 2 \\
\text { June } 2014 .\end{array}$ & $\begin{array}{l}\text { Uncertain } \\
\text { cause (fire) }\end{array}$ & $\begin{array}{l}\text { South Yorkshire, } \\
\text { England }\end{array}$ & $\begin{array}{l}\text { A large wood chip pile fire took place at R. Plevin \& Sons wood recycling } \\
\text { plant in Crow Edge (Yorkshire) on } 2 \text { June } 2014 .\end{array}$ \\
\hline $\begin{array}{l}\text { [63] Incident: } \\
2014 .\end{array}$ & Self-heating & Teeside, UK & $\begin{array}{l}\text { A series of fires occurred at a Teeside wood recycling company from } \\
\text { December } 2013 \text { until April } 2014 \text {. The company was fined as a result for } \\
\text { an environmental offence. The UK Wood Recycling (UKWR) plant was } \\
\text { ordered to pay } £ 71,335 \text { and a victim surcharge of } £ 120 \text { at a Teesside } \\
\text { Crown Court. No injuries. }\end{array}$ \\
\hline $\begin{array}{l}\text { [64] Incident: } \\
\text { March } 2014 .\end{array}$ & $\begin{array}{l}\text { Dust } \\
\text { explosion }\end{array}$ & $\begin{array}{l}\text { St. Augustine, } \\
\text { Florida (USA) }\end{array}$ & $\begin{array}{l}\text { Indianhead Biomass Services plant: An explosion occurred in March } \\
\text { 2014, injuring two workers. }\end{array}$ \\
\hline $\begin{array}{l}\text { [64] Incident: July } \\
2014 .\end{array}$ & $\begin{array}{l}\text { Dust } \\
\text { explosion }\end{array}$ & $\begin{array}{l}\text { St. Augustine, } \\
\text { Florida (USA) }\end{array}$ & $\begin{array}{l}\text { Indianhead Biomass Services plant: Another explosion occurred in July } \\
\text { 2014, injuring two workers. }\end{array}$ \\
\hline $\begin{array}{l}\text { [65] Incident: } \\
2014 .\end{array}$ & $\begin{array}{l}\text { Uncertain } \\
\text { cause (fire) }\end{array}$ & $\begin{array}{l}\text { Aurangabad, } \\
\text { India }\end{array}$ & $\begin{array}{l}\text { A pile of bagasse and biomass waste stored at the Shendra Green Energy } \\
\text { biomass power facility caught fire. No injuries. }\end{array}$ \\
\hline $\begin{array}{l}\text { [66] Incident: } \\
2015 .\end{array}$ & Self-heating & Montril, Spain & $\begin{array}{l}\text { A major fire broke out in a pile of biomass chips at the Las Azucenas dock } \\
\text { in Montril. No injuries. }\end{array}$ \\
\hline $\begin{array}{l}\text { [67] Incident: } \\
2015 .\end{array}$ & Self-heating & Tracy, USA & $\begin{array}{l}\text { A Tracy Storage Facility owned by Agra Marketing Group caught fire } \\
\text { after not following biomass pile size regulations. The facility is a } 40 \text {-acre } \\
\text { "storage and solar drying facility" for agricultural by-products. The fire } \\
\text { required } 500,000 \text { to } 1 \text { million gallons of water to extinguish the fire. No } \\
\text { reported injuries. }\end{array}$ \\
\hline $\begin{array}{l}\text { [66] Incident: } \\
\text { January } 2015 .\end{array}$ & Self-heating & $\begin{array}{l}\text { Fort St. John, } \\
\text { British Columbia }\end{array}$ & $\begin{array}{l}\text { A "hog pile" of leftover tree bark was believed to have spontaneously } \\
\text { combusted at a wood processing mill near Fort St. John, British Columbia. } \\
\text { It took eight hours to contain the fire. }\end{array}$ \\
\hline $\begin{array}{l}\text { [68] Incident: } 15 \\
\text { January } 2015 .\end{array}$ & $\begin{array}{l}\text { Uncertain } \\
\text { cause (fire) }\end{array}$ & $\begin{array}{l}\text { Port of } \\
\text { Southampton, } \\
\text { England }\end{array}$ & $\begin{array}{l}\text { Large biomass pile (owned by Eco Sustainable Solutions Limited) caught } \\
\text { on fire at King George Graving Dock on } 13 \text { January } 2015 .\end{array}$ \\
\hline $\begin{array}{l}\text { [40] Incident: } 30 \\
\text { January } 2015 .\end{array}$ & $\begin{array}{l}\text { Uncertain } \\
\text { cause (fire) }\end{array}$ & Motril, Spain & A major fire broke out in a pile of biomass chips on 30 January 2015. \\
\hline $\begin{array}{l}\text { [69] Incident: } 23 \\
\text { September } 2015 .\end{array}$ & $\begin{array}{l}\text { Dust } \\
\text { explosion } \\
\text { (suspected) }\end{array}$ & $\begin{array}{l}\text { Borssele, Zeeland } \\
\text { (Netherlands) }\end{array}$ & $\begin{array}{l}\text { Two explosions occurred in a biomass powerplant on } 23 \text { September } 2015 \text {, } \\
\text { were thought to be started by dust igniting in the biomass storage facility } \\
\text { which was being dismantled. Four people were hospitalized, two of } \\
\text { which were seriously injured. }\end{array}$ \\
\hline $\begin{array}{l}\text { [70] Incident: } 5 \\
\text { November } 2015 .\end{array}$ & Self heating & Port of Tyne, UK & $\begin{array}{l}\text { Wood pellets began to smolder in a cargo hold of a ship carrying 11,000 } \\
\text { tonnes of wood pellets (November 2015). } 100 \text { tonnes of smoldering } \\
\text { pellets were unloaded and left to cool on the dock side. }\end{array}$ \\
\hline $\begin{array}{l}\text { [71] Incident: } 15 \\
\text { December } 2015 .\end{array}$ & $\begin{array}{l}\text { Uncertain } \\
\text { cause (fire) }\end{array}$ & $\begin{array}{l}\text { Alexandra Docks, } \\
\text { (Newport) Wales, } \\
\text { UK }\end{array}$ & $\begin{array}{l}\text { 20,000 tons of woodchips caught fire on } 5 \text { December } 2015 \text { at the } \\
\text { Newport Docks. Several attempts were needed to put out the blaze. }\end{array}$ \\
\hline $\begin{array}{l}\text { [72] Incident: } 27 \\
\text { August } 2016 .\end{array}$ & $\begin{array}{l}\text { Uncertain } \\
\text { cause (fire) }\end{array}$ & $\begin{array}{l}\text { Ballachulish } \\
\text { Bridge, UK }\end{array}$ & $\begin{array}{l}\text { A building full of wood chips caught on fire near Ballachulish Bridge on } \\
27 \text { August 2016. No reported injuries. }\end{array}$ \\
\hline $\begin{array}{l}\text { [73] Incident: } 11 \\
\text { September } 2016 .\end{array}$ & $\begin{array}{l}\text { Uncertain } \\
\text { cause (fire) }\end{array}$ & $\begin{array}{l}\text { White City, } \\
\text { Oregon (USA) }\end{array}$ & $\begin{array}{l}2 \text { sawdust fires were reported from Biomass One on } 11 \text { September } 2016 \\
\text { (flames over } 25 \text { feet high). Fire origin was unclear. No reported injuries. }\end{array}$ \\
\hline $\begin{array}{l}\text { [74] Incident: } 12 \\
\text { March } 2017 .\end{array}$ & Self heating & $\begin{array}{l}\text { Chokchai district, } \\
\text { Thailand }\end{array}$ & $\begin{array}{l}500 \text { tonne biomass pile caught on fire at the Advanced Agro-Power Plant } \\
\text { in Tambon, Chokchai (Thailand) on } 12 \text { March } 2017 \text { due to } \\
\text { accumulated heat. }\end{array}$ \\
\hline $\begin{array}{l}\text { [75] Incident: } 12 \\
\text { April } 2017 .\end{array}$ & $\begin{array}{l}\text { Uncertain } \\
\text { cause (fire) }\end{array}$ & $\begin{array}{l}\text { Springfield, } \\
\text { Massachusetts } \\
\text { (USA) }\end{array}$ & $\begin{array}{l}\text { A wood chip silo fire at Springfield Power (owned by Korea East West } \\
\text { Power Company) took place on } 12 \text { April 2017. No serious injuries. }\end{array}$ \\
\hline $\begin{array}{l}\text { [76] Incident: } 15 \\
\text { April } 2017 .\end{array}$ & $\begin{array}{l}\text { Self heating } \\
\text { (suspected) }\end{array}$ & $\begin{array}{l}\text { Port Arthur, } \\
\text { Texas (USA) }\end{array}$ & $\begin{array}{l}\text { A persistent smoldering fire started in a wood pellets silo (German } \\
\text { Pellets) on Sat, } 15 \text { April 2017. It took } \sim 2 \text { weeks to completely extinguish } \\
\text { the fire. No injuries. }\end{array}$ \\
\hline
\end{tabular}


Table A1. Cont.

\begin{tabular}{|c|c|c|c|}
\hline $\begin{array}{l}\text { Reference \& } \\
\text { Incident Date }\end{array}$ & Category & Location & Description and Damages \\
\hline $\begin{array}{l}\text { [77] Incident: } 11 \\
\text { June } 2017 .\end{array}$ & $\begin{array}{l}\text { Uncertain } \\
\text { cause (fire) }\end{array}$ & $\begin{array}{l}\text { West Sussex, } \\
\text { England }\end{array}$ & $\begin{array}{l}\text { A fire occurred in a } 500 \text { tonne pile of wood chippings within a } 3000 \mathrm{~m}^{2} \\
\text { warehouse at Rabbit Waste Management (stored for incineration). No } \\
\text { reported injuries. }\end{array}$ \\
\hline $\begin{array}{l}\text { [78] Incident: } 10 \\
\text { June } 2017 .\end{array}$ & $\begin{array}{l}\text { Uncertain } \\
\text { cause (fire) }\end{array}$ & $\begin{array}{l}\text { Cottondale, } \\
\text { Florida (USA) }\end{array}$ & $\begin{array}{l}\text { Enviva's wood pellet mill caught fire on } 10 \text { June } 2017 \text {. Two workers were } \\
\text { treated for smoke inhalation. }\end{array}$ \\
\hline $\begin{array}{l}\text { [79] Incident: } 15 \\
\text { July } 2017 .\end{array}$ & $\begin{array}{l}\text { Self-heating } \\
\text { (suspected) }\end{array}$ & $\begin{array}{l}\text { Lumby, British } \\
\text { Columbia }\end{array}$ & $\begin{array}{l}\text { A wood chip pile (reserve pile for Tolka Industries) caught on fire in the } \\
\text { middle of Lundy, BC. The fire chief deemed the cause as being } \\
\text { spontaneous combustion. No reported injuries. }\end{array}$ \\
\hline $\begin{array}{l}\text { [80] Incident: } 24 \\
\text { August } 2017 .\end{array}$ & $\begin{array}{l}\text { Self Heating } \\
\text { (suspected) }\end{array}$ & $\begin{array}{l}\text { Prince George, } \\
\text { British Columbia }\end{array}$ & $\begin{array}{l}24 \text { August 2017: Finished pellets began smoldering in a silo at Pacific } \\
\text { Bioenergy Plant. No injuries. }\end{array}$ \\
\hline $\begin{array}{l}\text { [81] Incident: } 2 \\
\text { November } 2017 .\end{array}$ & $\begin{array}{l}\text { Uncertain } \\
\text { cause (fire) }\end{array}$ & $\begin{array}{l}\text { Williams Lake, } \\
\text { British Columbia }\end{array}$ & $\begin{array}{l}\text { A large fire occurred at Tolko's Lakeview sawmill in Williams Lake BC. } \\
\text { Several flare-ups took place afterwards. Significant damages were } \\
\text { incurred but no injuries were reported. }\end{array}$ \\
\hline $\begin{array}{l}\text { [82] Incident: } 29 \\
\text { December } 2017 .\end{array}$ & $\begin{array}{l}\text { Uncertain } \\
\text { cause (fire) }\end{array}$ & Kenora, Ontario & $\begin{array}{l}\text { A fire took place on } 29 \text { December } 2017 \text { at Kenora Forest Products sawmill. } \\
\text { Two kilns were destroyed (damages estimated at } \$ 850,000) \text {. No reported } \\
\text { injuries. }\end{array}$ \\
\hline $\begin{array}{l}\text { [83] Incident: } 6 \\
\text { February } 2018 .\end{array}$ & $\begin{array}{l}\text { Self heating } \\
\text { (suspected) }\end{array}$ & $\begin{array}{l}\text { Port Alberni, } \\
\text { British Columbia }\end{array}$ & $\begin{array}{l}\text { A fire took place at Western Forest Products' Alberni pacific Division Mill } \\
\text { (Port Alberni, BC) on } 6 \text { February. The fire was thought to have started in } \\
\text { a hog pile which was smoldering before fire crews arrived. }\end{array}$ \\
\hline
\end{tabular}




\section{Appendix B}

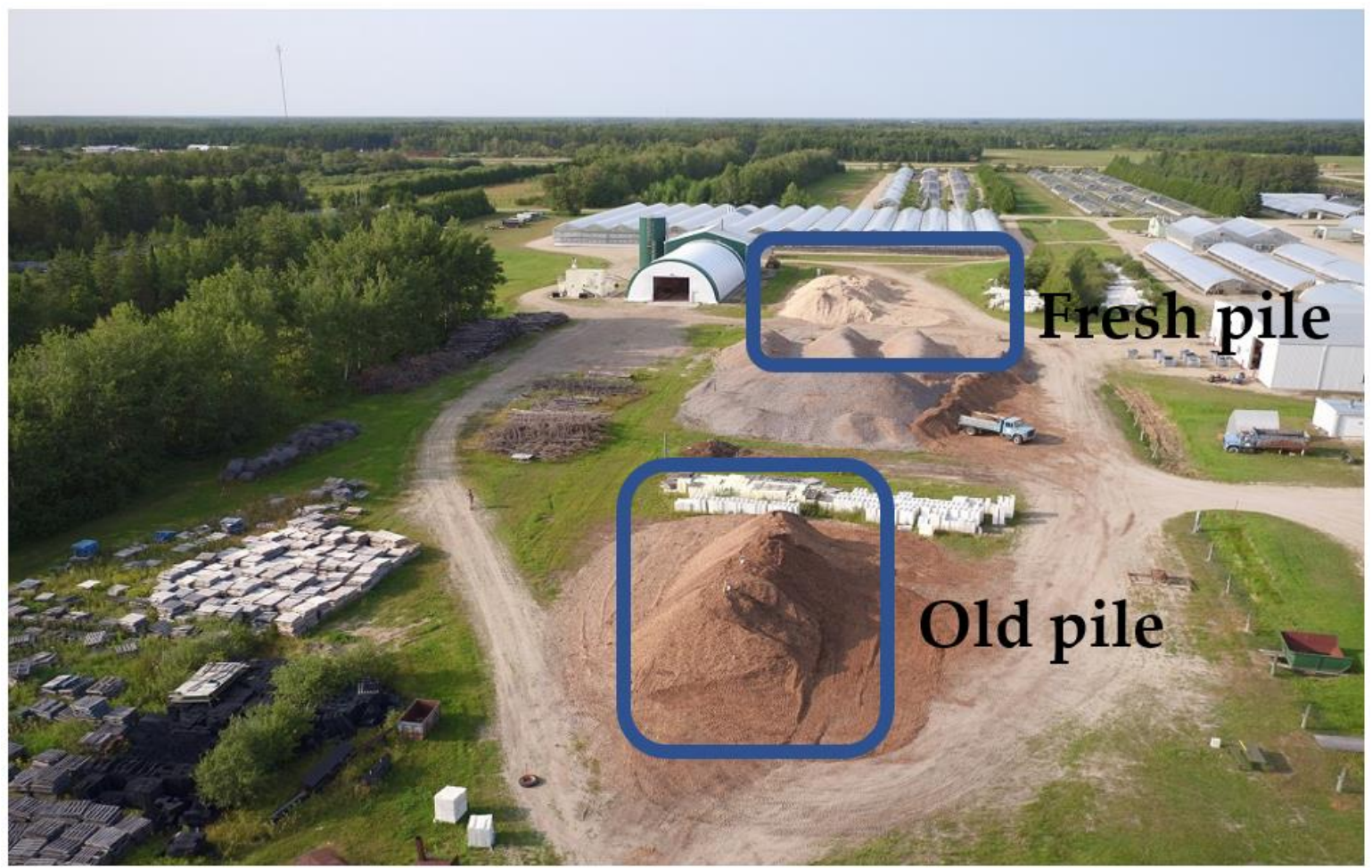

Figure A1. Aerial view of fresh (top) and old (bottom) experimental woodchip piles at Pineland Nurseries.

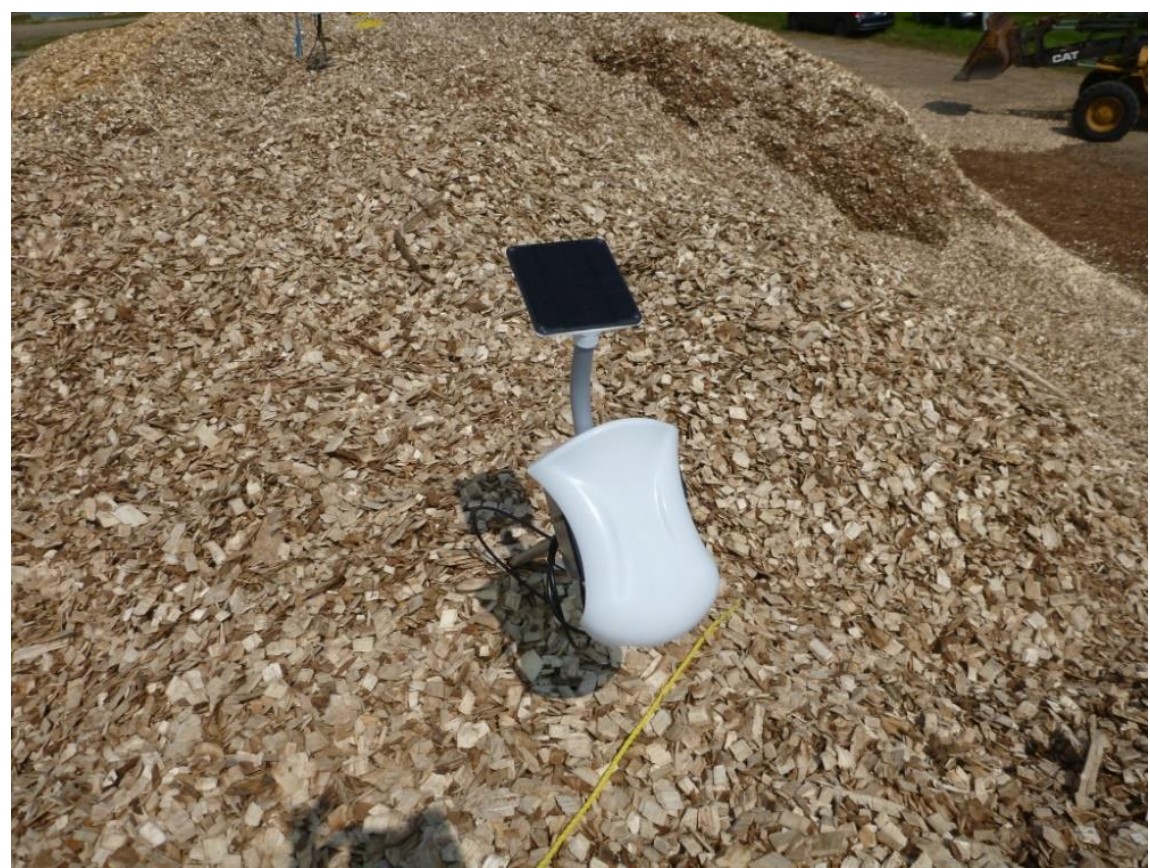

Figure A2. Braingrid real-time monitoring system (installed atop of the fresh woodchip pile). 


\section{Appendix C}

Table A2. Summary of compiled biomass storage incident reports from 2000-February 2018.

\begin{tabular}{|c|c|c|c|c|c|}
\hline Year & $\begin{array}{c}\text { Dust } \\
\text { Explosion }\end{array}$ & Self-Heating & $\begin{array}{l}\text { Uncertain } \\
\text { Cause (Fire) }\end{array}$ & $\begin{array}{l}\text { Off-Gassing } \\
\text { (Suffocation) }\end{array}$ & $\begin{array}{c}\text { Reported } \\
\text { Incident Total }\end{array}$ \\
\hline \multicolumn{6}{|l|}{2000} \\
\hline 2001 & 1 & & & & 1 \\
\hline 2002 & & & 1 & 1 & 2 \\
\hline 2003 & 2 & 1 & & 1 & 4 \\
\hline 2004 & & & 1 & & 1 \\
\hline 2005 & 1 & 1 & & 1 & 3 \\
\hline 2006 & & & 1 & 2 & 3 \\
\hline 2007 & & & 1 & 2 & 3 \\
\hline 2008 & & & & 1 & 1 \\
\hline 2009 & & 1 & & 1 & 2 \\
\hline 2010 & 1 & & & 2 & 3 \\
\hline 2011 & 1 & 1 & 1 & 1 & 4 \\
\hline 2012 & 3 & 2 & 1 & & 6 \\
\hline 2013 & 4 & 1 & & & 5 \\
\hline 2014 & 3 & 2 & 2 & & 7 \\
\hline 2015 & 1 & 4 & 3 & & 8 \\
\hline 2016 & & & 2 & & 2 \\
\hline 2017 & & 4 & 5 & & 9 \\
\hline 2018 & & 1 & & & 1 \\
\hline Total: & 17 & 18 & 18 & 12 & 65 \\
\hline
\end{tabular}

Table A3. Regional distribution of incident occurrence.

\begin{tabular}{cccccc}
\hline Incident Type & North America & Europe & $\begin{array}{c}\text { Scandinavia } \\
\text { (Denmark, } \\
\text { Norway, Sweden) }\end{array}$ & $\begin{array}{c}\text { Oceania (New } \\
\text { Zealand) }\end{array}$ & Asia \\
\hline Dust Explosion & 10 & 5 & 1 & 1 & \\
Self-heating & 9 & 7 & 1 & & 1 \\
Uncertain Cause (Fire) & 9 & 8 & 5 & & 2 \\
Off-Gassing & 1 & 6 & 5 & 1 & 2 \\
Total: & 29 & 26 & 7 & & 1 \\
\hline
\end{tabular}

\section{References}

1. Janze, P. Biomass Storage Pile Basics. 2011. Available online: http://www.advancedbiomass.com/2011/11/ biomass-storage-pile-basics / (accessed on 29 January 2018).

2. Sovacool, B.K.; Andersen, R.; Sorensen, S.; Sorensen, K.; Tienda, V.; Vainorius, A.; Schirach, O.A.; Bjørn-Thygesen, F. Balancing safety with sustainability: assessing the risk of accidents for modern low-carbon energy systems. J. Clean. Prod. 2016, 112, 3952-3965. [CrossRef]

3. Moreno, V.C.; Cozzani, V. Major accident hazard in bioenergy production. J. Loss Prev. Process Ind. 2015, 35, 135-144. [CrossRef]

4. Back, E.L. Auto-ignition in hygroscopic, organic materials-especially forest products-as initiated by moisture absorption from the ambient atmosphere. Fire Saf. J. 1981, 4, 185-196. [CrossRef]

5. Krigstin, S.; Wetzel, S. A Review of Mechanisms Responsible for Changes to Stored Woody Biomass Fuels. Fuel 2016, 175, 75-86. [CrossRef]

6. Stelte, W. Guideline: Storage and Handling of Wood Pellets. Available online: https://www.teknologisk.dk/_/ media/52682_RK\%20report\%20storage\%20and\%20handling\%20of\%20pellets.pdf (accessed on 28 March 2017).

7. Ferrero, F.; Lohrer, C.; Schmidt, B.; Noll, M.; Malow, M. A mathematical model to predict the heating-up of large-scale wood piles. J. Loss Prev. Process Ind. 2009, 22, 439-448. [CrossRef]

8. Hellenbrand, K.E.; Reade, A.E. Microorganisms associated with fuel wood chips and their impact on indoor air quality: A review. Int. Biodeterior. Biodegrad. 1992, 29, 19-43. [CrossRef] 
9. Ernstson, M.L.; Rasmuson, A. Mathematical modeling of transport processes and degradation reactions in piles of forest fuel material. Fuel 1993, 72, 1515-1524. [CrossRef]

10. Ashman, J.M.; Jones, J.M.; Williams, A. Some characteristics of the self-heating of the large scale storage of biomass. Fuel Process. Technol. 2018, 174, 1-8. [CrossRef]

11. HSE. Safe Handling of Combustible Dusts: Precautions Against Explosions. Health and Safety Executive Books. Available online: http:/ / www.hse.gov.uk/pUbns/priced/hsg103.pdf (accessed on 10 January 2018).

12. Wilen, C.; Rautalin, A. Handling and feeding of biomass to pressurized reactors: safety engineering. Bioresour. Technol. 1993, 46, 77-85. [CrossRef]

13. Koppejan, J.; Lönnermark, A.; Persson, H.; Larsson, I.; Blomqvist, P.; Arshadi, M.; Valencia-Reyes, E.; Melin, S.; Howes, P.; Wheeler, P.; et al. Health and Safety Aspects of Solid Biomass Storage, Transportation and Feeding. Available online: www.ieabioenergy.com/wp-content/uploads/2013/10/Health-and-SafetyAspects-of-Solid-Biomass-Storage-Transportation-and-Feeding.pdf (accessed on 28 March 2017).

14. Abbasi, T.; Abbasi, S.A. Dust explosions-Cases, causes, consequences, and control. J. Hazard. Mater. 2007, 140, 7-44. [CrossRef] [PubMed]

15. Simpson, A.; Sandys, V.; Stagg, S.; Pocock, D.; Hemingway, M. Safe Storage of Wood Pellets and Wood Chip Fuel (RR1077 Research Report). Health and Safety Executive Books. Available online: http:/ / www.hse.gov. uk/research/rrpdf/rr1077.pdf (accessed on 8 March 2018).

16. Svedberg, U.; Högberg, H.-E.; Högberg, J.; Galle, B. Emission of Hexanal and Carbon Monoxide from Storage of Wood Pellets, a Potential Occupational and Domestic Health Hazard. Ann. Occup. Hyg. 2004, 48, 339-349. [CrossRef]

17. NRC. Acute Exposure Guideline Levels for Selected Airborne Chemicals; The National Academies Press: Washington, DC, USA, 2010.

18. OSHA. Confined or Enclosed Spaces and Other Dangerous Atmospheres. United States Department of Labor. Available online: https://www.osha.gov/SLTC/etools/shipyard/shiprepair/confinedspace/ oxygendeficient.html (accessed on 8 March 2018).

19. HSE. Safe Work in Confined Spaces. Health and Safety Executive. Available online: www.hse.gov.uk/ pUbns/priced/1101.pdf (accessed on 2 February 2018).

20. NIOSH. Immediate Dangers to Life or Health (IDLH) Values. The National Institute for Occupational Safety and Health (NIOSH). Available online: https:/ / www.cdc.gov/niosh/idlh/intridl4.html (accessed on 29 February 2018).

21. OSHA. Health Hazards: Wood Dust. United States Department of Labor. Available online: https: / / www. osha.gov/SLTC/etools/sawmills/dust.html (accessed on 8 March 2018).

22. Crook, B.; Botheroyd, E.M.; Travers Glass, S.A.; Gould, J.R.M. The Exposure of Scottish Wood Bark Chip Handlers to Microbially Contaminated Airborne Dust. Ann. Occup. Hyg. 1994, 38, 903-906. [CrossRef]

23. Makridakis, S.S.C. Wheel Wright. In Forecasting: Methods and Applications, 3rd ed.; John Wiley and Sons: New York, NY, USA, 1988.

24. Maia, A.; de Carvalho, F. Holt's exponential smoothing and neural network models for forecasting interval-valued time series. Int. J. Forecast. 2011, 27, 740-759. [CrossRef]

25. Hanke, J.E.; Wichern, D.W. Business Forecasting, 8th ed.; Pearson Education International: Harlow, UK, 2008.

26. Johnson, D. Investigating Claims Involving Spontaneous Combustion (May 21). Available online: http: / / www.claimsjournal.com/news/national/2013/05/21/229361.htm (accessed on 28 March 2017).

27. Hoekstra, G. WorkSafeBC Pinpoints Wood-Dust Concerns at Pellet Plants (January 5). Available online: http:/ / www.vancouversun.com/WorkSafeBC+pinpoints+wood+dust+concerns+pellet+plants / 10089375/story.html (accessed on 1 February 2018).

28. CBC News. Babine Forest Products fined $\$ 1 \mathrm{M}$ for Burns Lake Sawmill Explosion (April 3). Available online: www.cbc.ca/news/canada/british-columbia/babine-forest-products-fined-1m-for-burns-lakesawmill-explosion-1.2597280 (accessed on 7 February 2018).

29. Chisholm, J. Deadly BC Wood Dust Explosions Place Emphasis on Precautions. Available online: https:/ / www.mcscs.jus.gov.on.ca/english/FireMarshal/FireServiceResources/messenger/OFM_Mr_ 2014-01_A5.html (accessed on 9 March 2018).

30. Murray, G. WPAC-Proper Handling of Wood Pellets. Available online: https://www. canadianbiomassmagazine.ca/pellets/wpac----proper-handling-5899 (accessed on 2 February 2018). 
31. WPAC. Material Safety Data Sheet for Wood Pellets in Bulk. Available online: https://www.pellet.org/ images/2009-05-05_MSDS_Bulk_Pellets.pdf (accessed on 1 March 2018).

32. Gauthier, S.; Grass, H.; Lory, M.; Kramer, T.; Thali, M.; Bartsch, C. Lethal Carbon Monoxide Poisoning in Wood Pellet Storerooms-Two Cases and a Review of the Literature. Ann. Occup. Hyg. 2012, 56, 755-763. [CrossRef]

33. Simpson, A.; Hemingway, A.; Seymour, C. Dangerous (toxic) atmospheres in UK wood pellet and wood chip fuel storage. J. Occup. Environ. Hyg. 2016, 13, 699-707. [CrossRef] [PubMed]

34. Tremier, A.; de Guardia, A.; Massiani, C.; Paul, E.; Martel, J.L. A respirometric method for characterising the organic composition and biodegradation kinetics and the temperature influence on the biodegradation kinetics, for a mixture of sludge and bulking agent to be co-composted. Bioresour. Technol. 2005, 96, 169-180. [CrossRef] [PubMed]

35. Torrent, J.G.; Anez, N.F.; Pejic, L.M.; Mateos, L.M. Assessment of self-ignition risks of solid biofuels by thermal analysis. Fuel 2015, 143, 484-491. [CrossRef]

36. Blijderveen, M.; Gucho, E.M.; Bramer, E.A.; Brem, G. Spontaneous ignition of wood, char and RDF in a lab scale packed bed. Fuel 2010, 89, 2393-2404. [CrossRef]

37. Taraba, B.; Podstawka, T.; Mucha, M. Towards indication gases of spontaneous heating of biomass. Fuel 2018, 222, 610-616. [CrossRef]

38. Rentizelas, A.A.; Tolis, A.J.; Tatsiopoulos, I.P. Logistics issues of biomass: the storage problem and the multi-biomass supply chain. Renew. Sustain. Energy Rev. 2009, 13, 887-894. [CrossRef]

39. ARIA. 20579. Republique Francais. Available online: https://www.aria.developpement-durable.gouv.fr/ accident/20579_en/?lang=en (accessed on 9 March 2018).

40. The Biomass Monitor. [Exclusive] Bioenergy Industry Fires and Explosions. Available online: https: / / thebiomassmonitor.org/2015/01/10/biomass-industry-plays-with-fire-gets-burned-2/ (accessed on 20 January 2018).

41. ARIA. Fire and Explosion in Sawdust Silo. Available online: https://www.aria.developpement-durable. gouv.fr/accident/24332_en/?lang=en (accessed on 9 March 2018).

42. ARIA. Silo Explosion Followed by Fire. Available online: https://www.aria.developpement-durable.gouv. fr/accident/24555_en/?lang=en (accessed on 9 March 2018).

43. ARIA. 25978. Republique Francais. Available online: https://www.aria.developpement-durable.gouv.fr/ accident/25978_en/?lang=en (accessed on 9 March 2018).

44. ARIA. Softwood Chips Fire. Available online: https://www.aria.developpement-durable.gouv.fr/accident/ 26931_en/?lang=en (accessed on 9 March 2018).

45. ARIA. Explosion of A Woodchip Refiner and Fire. Available online: https://www.aria.developpementdurable.gouv.fr/fiche_detaillee/29011_en/?lang=en (accessed on 9 March 2018).

46. Kooren, R. Demystifying the Source of Mysterious Fires. Available online: www.origin-and-cause.com/ resources/blog/the-subtle-signature-of-spontaneous-combustion (accessed on 1 February 2018).

47. Fitch, J. Firefighters Respond to Blaze at AJ Stove \& Pellet (August 2). Available online: http://articles. herald-mail.com/2010-08-02/news /25197644_1_fire-marshal-franklin-county-air-unit-firefighters (accessed on 7 February 2018).

48. Stepzinski, T. Explosion Damages Waycross Plant; No Injuries Reported (June 21). Available online: http:/ /jacksonville.com/news/crime/2011-06-21/story/explosion-damages-waycross-plant-no-injuriesreported\# (accessed on 29 January 2018).

49. Butcher, J. Firefighters Battle Huge Biomass Fire at Port of Tyne (June 25). Available online: http: / / www.thejournal.co.uk/news/north-east-news/ firefighters-battle-huge-biomass-fire-4422494 (accessed on 7 February 2018).

50. Read, S. Winds Fan Feedlot Fire (November 23). Available online: www.nantonnews.com/2011/11/23/ winds-fan-feedlot-fire (accessed on 10 January 2018).

51. Jones, S. Firefighters Battle Essex Power Station Blaze (February 27). Available online: https://www. theguardian.com/uk/2012/ feb/27 / firefighters-essex-power-station-blaze (accessed on 7 February 2018).

52. CPH Post. Amager Explosion Injures Three (May 11). Available online: http://cphpost.dk/news/localnews/amager-explosion-injures-three.html (accessed on 7 February 2018). 
53. CPH Post. Fire at City Power Plant Expected to Burn for Days (December 17). Available online: http: / / cphpost.dk/news/local-news/ fire-at-city-power-plant-expected-to-burn-for-days.html (accessed on 7 February 2018).

54. Robinson, R. Silo Fire Hits Upper Leacock Business (March 5). Available online: http:/ / lancasteronline.com/ news/silo-fire-hits-upper-leacock-business/article_bc401650-241e-5aa2-8ee5-3c1200e3b763.html (accessed on 7 February 2018).

55. NBC 10 News. Fire Chief: Dust Caused Pellet Company Explosion (August 20). Available online: http: / / turnto10.com/archive/fire-reported-at-east-providence-wood-pellet-company (accessed on 5 February 2018).

56. Bock, L. Fire Badly Damages Fitchburg Mill (November 13). Available online: http:/ /www.telegram.com/ article/20131113/news/131119976 (accessed on 18 January 2018).

57. Beaumont Enterprise. German Pellet Plant in Woodville Has Fire in Silo (April 30). Available online: http:/ / www.beaumontenterprise.com/jasper/news/article/German-pellet-Plant-in-Woodvillehas-fire-in-Silo-5442052.php (accessed on 19 January 2018).

58. Waikato Times. Fire after Sawdust Explosion (September 3). Available online: http://www.stuff.co.nz/ waikato-times/news/9122122/Fire-after-sawdust-explosion (accessed on 29 January 2018).

59. Shaffer, D. Restart of Koda Energy Power Plant Uncertain (May 3). Available online: http:/ /www.startribune. com/restart-of-koda-energy-power-plant-uncertain/206053941/?refer=y (accessed on 11 January 2018).

60. Telegraph Derby. Arcwood Recycling Boss Admits Putting Life at Risk after Fire Burned in Stanton-by-Dale for Two Months (February 24). Available online: http:/ /www.derbytelegraph.co.uk/month-blaze-arcwoodrecycling-boss-admits-putting/story-20686427-detail/story.html\#VCBe9mvXXTTgpgz8.99 (accessed on 29 January 2018).

61. ICHEME. Firefighters among Seven Hurt in Forres Silo Explosion (29 April 2014). Loss Prevention Bulletin. Available online: http:/ / www.icheme.org/lpb/news/2014/140429-firefighters-among-seven-hurtin-forres-silo-explosion (accessed on 28 March 2018).

62. The Star News. Firefighters Remain at Biomass Depot in South Yorkshire (June 3). Available online: http: / / www.thestar.co.uk/news / firefighters-remain-at-biomass-depot-in-south-yorkshire-1-6652028 (accessed on 29 January 2018).

63. Preston, R. Teesside Wood Recycler Fined after Blaze (November 25, 2014). Available online: https: / / www. mrw.co.uk/latest/teesside-wood-recycler-fined-after-blaze/10015194.article (accessed on 10 January 2018).

64. OSHA. Indianhead Biomass Services Explosion Severely Injures 2 Workers 2nd Explosion in 4 Months Results in more OSHA Citations. Available online: https:/ /www.osha.gov/news/newsreleases/region6/01292015 (accessed on 7 February 2018).

65. The Times of India. Major Fire Breaks out at Biomass Waste Power Plant (June 23). Available online: http: / / timesofindia.indiatimes.com/city/aurangabad/Major-fire-breaks-out-at-biomass-wastepower-plant/articleshow/37067482.cms (accessed on 20 January 2018).

66. Euroweekly News. Firefighters Tackle Biomass Blaze at Motril Harbour (February 2). Available online: https:/ / www.euroweeklynews.com/3.0.15/index.php/news/on-euro-weekly-news/axarquia-costatropical/item/125588-firefighters-tackle-biomass-blaze-at-motril-harbour (accessed on 1 February 2018).

67. Moore, G. Improper Practices Fueled Fire (May 21). Available online: http:/ /www.goldenstatenewspapers. com/tracy_press/news/improper-practices-fueled-fire/article_9388f1ba-000f-11e5-b7d2-2b5656d08c03. html (accessed on 19 January 2018).

68. Southern Daily Echo. Fears Raised over Impact of Controversial Biomass Plant after Woodchip Blaze at Southampton Docks (January 15). Available online: http:/ /www.dailyecho.co.uk/news/11724303.DOCKS_ FIRE_Fears_over_biomass_plant_reignited_after_woodchip_blaze/ (accessed on 7 February 2018).

69. Walsh, L. Four Injured after Explosions at Part Biomass-Fired Plant (September 23). Available online: http:/ / www.endswasteandbioenergy.com/article/1365364/four-injured-explosions-part-biomassfired-plant (accessed on 7 February 2018).

70. Silfverskoild, P. Massive Emergency Response to Fire Alert on Ship Carrying 11,000 Tonnes of Wood Pellets in Port of Tyne (November 5). Available online: http:/ / www.shieldsgazette.com/news/massive-emergencyresponse-to-fire-alert-on-ship-carrying-11-000-tonnes-of-wood-pellets-in-port-of-tyne-1-7554167 (accessed on 7 February 2018).

71. BBC News. Wood Recycling Firm Fined 20,000 for Newport Docks Fire (November 10). Available online: www.bbc.com/news/uk-wales-south-east-wales-37935807 (accessed on 18 January 2018). 
72. Campbell, R. Fire Crews Tackle Burning Woodchip Building (August 27). Available online: https:/ / www. pressandjournal.co.uk/fp/news/highlands / 1009447 / fire-crews-tackle-burning-woodchip-building/ (accessed on 18 January 2018).

73. Stiles, G. Firefighters Battle Fire at Biomass One. Mail Tribune (September 11). Available online: www. mailtribune.com/news/20160911/ (accessed on 30 January 2018).

74. The Nation. Sunday's Fire at Power Plant's Biomass Fuels Pile Put out Monday (March 13). Available online: http:/ / www.nationmultimedia.com/detail/breakingnews/30308923 (accessed on 29 January 2018).

75. Wolfe, R. Big Response to Fire in Woodchip Silo at Springfield Power (April 12). Available online: www. vnews.com/Fire-in-Springfield-9234812 (accessed on 8 February 2018).

76. Kotrba, R. Mitigating Pellet Silo Fires (July 26). Available online: http:/ /biomassmagazine.com/articles / 14548/mitigating-pellet-silo-fires (accessed on 7 February 2018).

77. Perchard, E. Firefighters Containing Large Wood Chip Fire at EFW Site. Available online: https:/ / resource. co/article/firefighters-containing-large-wood-chip-fire-efw-site-11918 (accessed on 29 February 2018).

78. Voegele, E. Enviva's Cottondale Plant Idle Less than 1 Day Following Fire (June 12). Available online: http:/ / biomassmagazine.com/articles/14445/envivaundefineds-cottondale-plant-idle-less-than1-day-following-fire (accessed on 20 January 2018).

79. Bouey, K. Wood Chip Pile Fire Doused (July 16). Available online: https://www.castanet.net/news/Vernon/ 201931/Wood-chip-pile-fire-doused (accessed on 7 February 2018).

80. Nielsen, M. Workers Removing Smouldering Pellets from Silo at Pacific Bioenergy (August 25). Available online: www.princegeorgecitizen.com/news/local-news/workers-removing-smouldering-pellets-fromsilo-at-pacific-bioenergy-1.22177481 (accessed on 8 February 2018).

81. CBC News. Fire Continues to Flare up at Williams Lake, B.C. Sawmill. Available online: www.cbc.ca/news / canada/british-columbia/fire-tolko-williams-lake-1.4389411 (accessed on 7 February 2018).

82. Atik, T. Extensive Fire at Kenora Sawmill Destroys Two Kilns (January 2). Available online: https:/ / www. woodbusiness.ca/sawmilling/health-safety/sawmill-fire-in-kenora-destroys-two-kilns-4681 (accessed on 10 January 2018).

83. Atik, T. Hog Pile Fire at Western Forest Products Mill in Port Alberni, BC (February 13). Available online: https:/ / www.woodbusiness.ca/industry-news/news/hog-pile-fire-at-western-forest-productsmill-in-port-alberni-bc-4743 (accessed on 29 February 2018).

(C) 2018 by the authors. Licensee MDPI, Basel, Switzerland. This article is an open access article distributed under the terms and conditions of the Creative Commons Attribution (CC BY) license (http://creativecommons.org/licenses/by/4.0/). 